\title{
Endocytosis of Viruses and Bacteria
}

\author{
Pascale Cossart ${ }^{1}$ and Ari Helenius ${ }^{2}$ \\ ${ }^{1}$ Institut Pasteur, Unité des Interactions Bactéries-Cellules, Paris F-75015, France; INSERM U604, \\ Paris F-75015, France; and INRA, USC2020, Paris F-75015, France \\ ${ }^{2}$ Institute of Biochemistry, ETH Zurich, 8093 Zurich, Switzerland \\ Correspondence: pcossart@pasteur.fr; ari.helenius@bc.biol.ethz.ch
}

\begin{abstract}
Of the many pathogens that infect humans and animals, a large number use cells of the host organism as protected sites for replication. To reach the relevant intracellular compartments, they take advantage of the endocytosis machinery and exploit the network of endocytic organelles for penetration into the cytosol or as sites of replication. In this review, we discuss the endocytic entry processes used by viruses and bacteria and compare the strategies used by these dissimilar classes of pathogens.
\end{abstract}

M any of the most widespread and devastating diseases in humans and livestock are caused by viruses and bacteria that enter cells for replication. Being obligate intracellular parasites, viruses have no choice. They must transport their genome to the cytosol or nucleus of infected cells to multiply and generate progeny. Bacteria and eukaryotic parasites do have other options; most of them can replicate on their own. However, some have evolved to take advantage of the protected environment in the cytosol or in cytoplasmic vacuoles of animal cells as a niche favorable for growth and multiplication. In both cases (viruses and intracellular bacteria), the outcome is often destructive for the host cell and host organism. The mortality and morbidity caused by infectious diseases worldwide provide a strong rationale for research into pathogen-host cell interactions and for pursuing the detailed mechanisms of transmission and dissemination. The study of viruses and bacteria can, moreover, provide in- valuable insights into fundamental aspects of cell biology.

Here, we focus on the mechanisms by which viral and bacterial pathogens exploit the endocytosis machinery for host cell entry and replication. Among recent reviews on this topic, dedicated uniquely to either mammalian viruses or bacterial pathogens, we recommend the following: Cossart and Sansonetti (2004); Pizarro-Cerda and Cossart (2006); Kumar and Valdivia (2009); Cossart and Roy (2010); Mercer et al. (2010b); Grove and Marsh (2011); Kubo et al. (2012); Vazquez-Calvo et al. (2012a); Sun et al. (2013).

The term "endocytosis" is used herein in its widest sense, that is, to cover all processes whereby fluid, solutes, ligands, and components of the plasma membrane as well as particles (including pathogenic agents) are internalized by cells through the invagination of the plasma membrane and the scission of membrane vesicles or vacuoles. This differs from current practice in

Editors: Sandra L. Schmid, Alexander Sorkin, and Marino Zerial

Additional Perspectives on Endocytosis available at www.cshperspectives.org

Copyright (C) 2014 Cold Spring Harbor Laboratory Press; all rights reserved; doi: 10.1101/cshperspect.a016972

Cite this article as Cold Spring Harb Perspect Biol 2014;6:a016972 
the bacterial pathogenesis field, where the term "endocytosis" is generally reserved for the internalization of molecules or small objects, whereas the uptake of bacteria into nonprofessional phagocytes is called "internalization" or "bacterial-induced phagocytosis." In addition, the term "phagocytosis" is reserved for internalization of bacteria by professional phagocytes (macrophages, polymorphonuclear leucocytes, dendritic cells, and amoebae), a process that generally but not always leads to the destruction of the ingested bacteria (Swanson et al. 1999; May and Machesky 2001; Henry et al. 2004; Zhang et al. 2010). With a few exceptions, we will not discuss phagocytosis of bacteria or the endocytosis of protozoan parasites such as Toxoplasma and Plasmodium (Robibaro et al. 2001).

\section{VIRUSES}

Viruses are lifeless particles lacking metabolism and means of locomotion. Their mission (raison d'être) is to serve as carriers for their own genome during cell-to-cell spread and organism-to-organism transmission. They protect the genome (RNA or DNA) during transit, and deliver it into the cytosol or the nucleus of new host cells usually together with accessory proteins. Although often spherical, mammalian viruses can be bullet-shaped, brick-shaped, amorphous, or filamentous ranging in diameter from 18 to $\sim 2000 \mathrm{~nm}$.

In enveloped animal viruses, the membrane is a de facto transport vesicle. It is formed by budding (fission) from membranes in the infected cell. It releases its cargo (a nucleocapsid and accessory proteins) by fusing with a membrane in the new host cell. In this way, there is no need for macromolecule complexes to ever cross a membrane. To overcome the membrane barriers, nonenveloped viruses induce membrane lysis, generate pores, or rely on membranecrossing devices provided by the cell. The majority of nonenveloped and enveloped viruses depend on endocytosis for entry. This means that the penetration reaction-whether by fusion or other mechanisms-occurs in intracellular organelles and involves intracellular membranes of the host cell.

\section{BACTERIA}

Although the simplest among living organisms, bacteria are considerably more complex than viruses. They are single-celled and have different shapes (spherical, spiral, or rod shaped) and appear singly or in chains. A typical bacterium is $1-5 \mu \mathrm{m}$ in length. It has a cell membrane and a rigid cell wall, and it lacks a nucleus. Some have an additional outer membrane, and some have appendages such as flagella that they use to move in the environment or pili that they use for adhesion to inert surfaces, host cells, and even to other bacteria.

In contrast to viruses, bacteria can secrete proteins including toxins via a variety of secretion systems, classified from I to VII depending on the structure and organization of the secretion machinery. Highly relevant for this review are the type III and the type IV secretion systems, which appear as nanomachines on the bacterial surface (Backert and Meyer 2006; Thanassi et al. 2012). They are dedicated to the transport of effector proteins directly from the interior of the bacteria into the interior of the host eukaryotic cell. These effector proteins are either enzymes that use host components as substrates or proteins that structurally or functionally mimic eukaryotic proteins and thus interfere with cellular mechanisms (Galan and Wolf-Watz 2006; Agbor and McCormick 2011).

Many pathogenic bacteria multiply extracellularly, but it is increasingly recognized that many bacteria that were long considered extracellular can also reside, replicate, or persist inside cells (Pizarro-Cerda and Cossart 2006). Depending on the type of host cells ( phagocytic or nonphagocytic) with which bacteria interact, there are two possible scenarios. In phagocytic cells such as macrophages, cells are the active players in the internalization process; they engulf bacteria and internalize them. In contrast, in nonphagocytic cells, only a few bacterial species-qualified as "invasive"-enter as the result of a process that the bacteria initiate. Some bacteria have obligate intracellular life styles like viruses; that is, they cannot replicate outside a eukaryotic cell. Generally, these bacteria have lost genes required for independent 
replication in broth medium and have small genomes. Nevertheless, as recently shown for Coxiella burnetii, the use of complex media may provide nutrients for extracellular replication of pathogens up to now considered as obligate intracellular pathogens (Omsland et al. 2009).

\section{ENDOCYTOSIS OF VIRUSES AND BACTERIA: THE GENERAL PICTURE}

There are many reasons why incoming pathogens enter host cells by endocytosis for replication.

In the case of bacteria, entry into cells and replication therein are believed to protect them from circulating antibodies and complementinduced destruction. Yet, inside cells, pathogens have to confront a variety of cellular defense mechanisms. They have evolved numerous sophisticated mechanisms to counteract these bactericidal processes. Specifically, they may secrete proteins or components that either allow modification of the internalization vacuole to permit an intravacuolar lifestyle with concomitant replication or trigger escape from the vacuole (Kumar and Valdivia 2009). Of the bacteria that escape from vacuoles, some are able to recruit actin and move intra- and intercellularly (Gouin et al. 2005). Others simply multiply without further movement within the nutrient-rich environment of the cytosol. In this case, cell lysis leads to pathogen dissemination. It is to be noted that for intracytosolic bacteria, entry into the cytosol involves lysis of intracellular vacuoles. This is likely to be less damaging for the cell than if it occurred directly through the plasma membrane.

For viruses, endocytic vesicles help to ferry the incoming particles deep into the cytoplasm unobstructed by cytoplasmic crowding and obstacles such as the cytoskeleton. In the process of intracellular maturation of endocytic vacuoles, the host cell exposes the viruses to changing conditions including a drop in $\mathrm{pH}$ that many viruses use as a cue to activate penetration (Helenius et al. 1980; Vazquez-Calvo et al. 2012a). Exposure to proteases and processing of viral proteins is critical for some viruses because it allows activation of viral penetration and uncoating mechanisms (Danthi et al. 2010; Hunt et al. 2012; Kubo et al. 2012). By fusing their envelope with membranes of internal organelles, enveloped viruses can, moreover, avoid exposing their glycoproteins on the cell surface, and can thus presumably delay detection by immune surveillance. Some enveloped viruses belonging to the retro-, paramyxo-, pox-, and herpesviruses can, however, release their capsids into the cytosol by fusing their envelope membrane with the plasma membrane. In most cases, it is not clear whether such fusion results in infection because virus particles are also being endocytosed in the same cells, and these could be the ones causing infection.

Unlike many of the invasive bacteria, incoming viruses cannot manipulate the endocytic machinery by prior delivery of effector proteins into the cytosol of host cells. To induce endocytosis and prepare the host cell for invasion, they make use of the cell's signaling and regulatory pathways, but they do so indirectly from the plasma membrane.

\section{VIRUS BINDING TO HOST CELLS}

Endocytic entry of viruses occurs in a stepwise manner involving attachment to the cell surface, clustering of receptors, activation of signaling pathways, formation of endocytic vesicles and vacuoles, delivery of viral cargo to endosomal compartments, sorting, and escape into the cytosol. Depending on the virus, capsid escape occurs from early endosomes, late endosomes, lysosomes, macropinosomes, or the endoplasmic reticulum (ER) (Fig. 1; Table 1). Possible additional locations include the trans-Golgi network (TGN), the Golgi complex, recycling endosomes, or amphisomes (Suikkanen et al. 2002; Berryman et al. 2012; Day et al. 2013; Lipovsky et al. 2013).

Viruses only infect cells to which they can bind. The choice of receptors and the specificity of binding contribute to the choice of entry mechanism, to species and tissue specificity of infection, to cell tropism, and ultimately to the course of the disease. Enveloped viruses bind via spike glycoproteins, whereas nonenveloped viruses usually attach via fibers, spikes, or sur- 


\section{P. Cossart and A. Helenius}

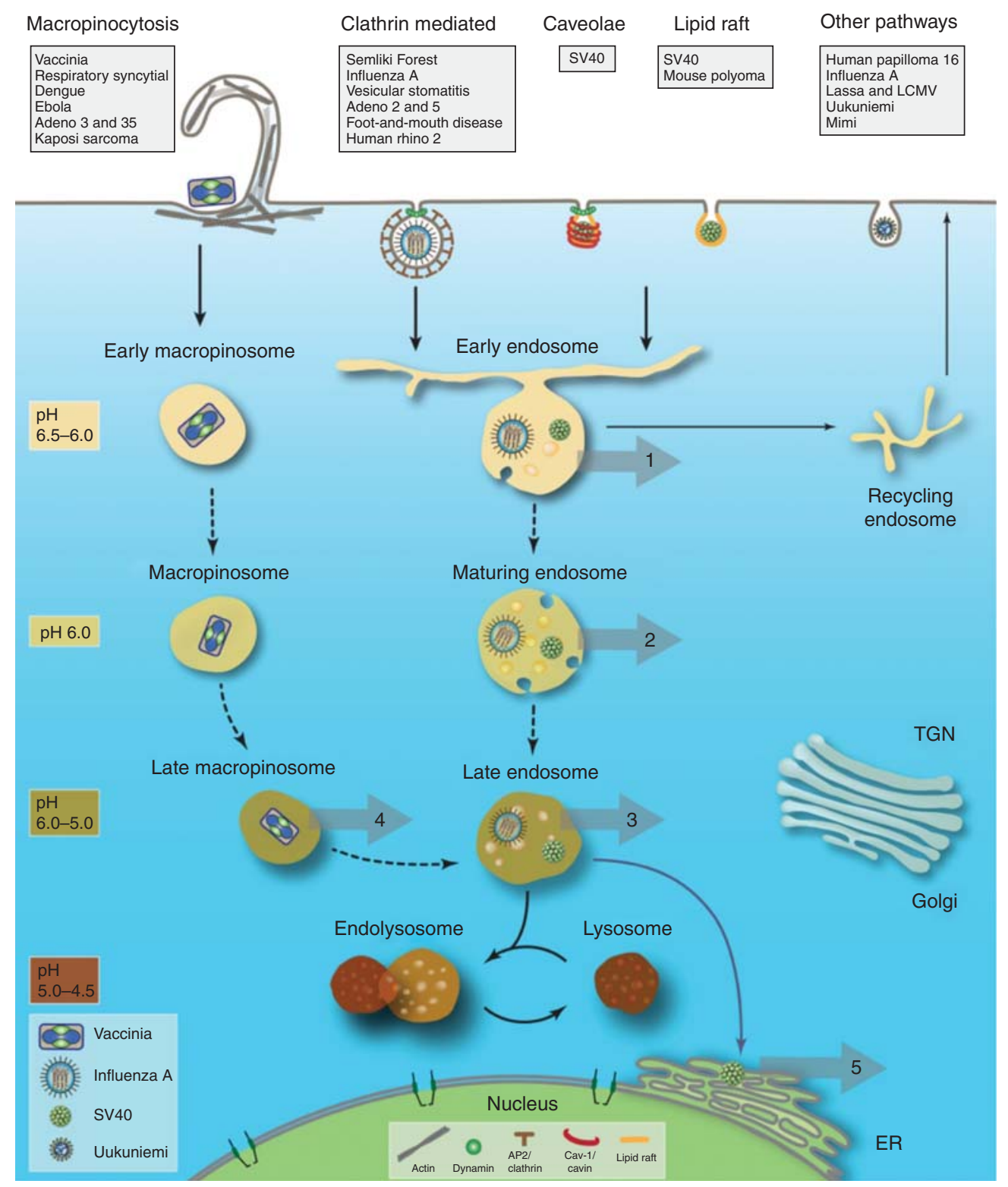

Figure 1. Viruses in the endocytic network. After binding to cell-surface receptors, viruses are internalized through a variety of endocytic processes including macropinocytosis, clathrin-mediated endocytosis, caveolae, and clathrin- and caveolin-independent mechanisms. Some of the viruses that use these mechanisms of endocytosis are listed. The primary endocytic vesicles and vacuoles formed ferry incoming virus particles into the endocytic network, where they undergo sorting and eventually penetration into the cytosol from different locations within the vacuolar network. Five different locations are indicated by the numbered gray arrows. Pathways followed by influenza A virus, SV40, Uukuniemi virus, and vaccinia virus are shown. Of these, SV40 is transported to the endoplasmic reticulum for uncoating and penetration, whereas influenza A and vaccinia virus undergo acid-activated membrane fusion in maturing and late endosomes and macropinosomes, respectively. The location and timing of escape are often determined by the $\mathrm{pH}$ threshold for penetration of the virus particles as indicated. LCMV, lymphocytic choriomeningitis virus. 


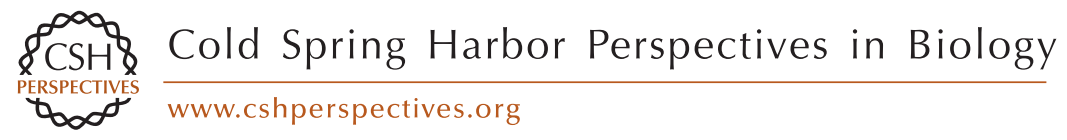

Table 1. Examples of viruses and their endocytosis

\begin{tabular}{|c|c|c|c|c|c|}
\hline Virus & Family & Receptor & Penetration & Cell type & References \\
\hline \multicolumn{6}{|c|}{ Clathrin-mediated endocytosis } \\
\hline Semliki Forest virus & $\begin{array}{l}\text { Togaviridae } \\
\text { Enveloped } \\
\text { ss }(+) \text { RNA }\end{array}$ & Not known & $\begin{array}{l}\mathrm{pH}<6.2 \\
\text { Early endosome }\end{array}$ & BHK-21 & Helenius et al. 1980; Doxsey et al. 1987 \\
\hline Vesicular stomatitis virus & $\begin{array}{l}\text { Rhabdoviridae } \\
\text { Enveloped } \\
\text { ss }(-) \text { RNA }\end{array}$ & $\begin{array}{l}\text { LDL receptor and family } \\
\text { members }\end{array}$ & $\begin{array}{l}\mathrm{pH}<6.4 \\
\text { Early endosome }\end{array}$ & MDCK & $\begin{array}{l}\text { Matlin et al. 1982; Cureton et al. 2009; } \\
\text { Johannsdottir et al. } 2009\end{array}$ \\
\hline Influenza A virus & $\begin{array}{l}\text { Myxoviridae } \\
\text { Enveloped } \\
\text { ss }(-) \text { RNA }\end{array}$ & $\begin{array}{l}\text { Sialic acid containing } \\
\text { glycoconjugates }\end{array}$ & $\begin{array}{l}\mathrm{pH}<5.4 \\
\text { Early endosome }\end{array}$ & MDCK, BS-C-1 & Matlin et al. 1981; Rust et al. 2004 \\
\hline $\begin{array}{l}\text { Foot-and-mouth disease } \\
\text { virus }\end{array}$ & $\begin{array}{l}\text { Picornaviridae } \\
\text { Nonenveloped } \\
\text { ss }(+) \text { RNA }\end{array}$ & $\begin{array}{l}\text { Integrins } \\
\alpha 2 \beta 1 / \alpha v \beta 3, \alpha v \beta 6\end{array}$ & $\begin{array}{l}\text { Early endosome } \\
\text { Recycling endosome }\end{array}$ & $\begin{array}{l}\text { BHK21, MCF-10A } \\
\text { SW480 }\end{array}$ & $\begin{array}{l}\text { Berinstein et al. 1995; Berryman et al. } \\
\text { 2005; O'Donnell et al. 2005; Johns et al. } \\
2009\end{array}$ \\
\hline Rhinovirus (HRV2) & Picornaviridae & LDL-receptor & $\mathrm{pH}<5.5$ & HeLa & Fuchs and Blaas 2012 \\
\hline Minor group & $\begin{array}{l}\text { Nonenveloped } \\
\text { ss(+)RNA }\end{array}$ & VLDL-receptor & endosome & & \\
\hline Adenovirus 2 & $\begin{array}{l}\text { Adenoviridae } \\
\text { Nonenveloped } \\
\text { dsDNA }\end{array}$ & $\begin{array}{l}\text { CAR } \\
\text { Integrins } \alpha v \beta, \alpha v \beta 5\end{array}$ & Endosome & HeLa & Wickham et al. 1993; Meier et al. 2002 \\
\hline \multicolumn{6}{|l|}{ Macropinocytosis } \\
\hline $\begin{array}{l}\text { Vaccinia virus } \\
\text { Mature particle (MV) } \\
\text { Enveloped particle (EV) }\end{array}$ & $\begin{array}{l}\text { Poxviridae } \\
\text { Enveloped } \\
\text { dsDNA }\end{array}$ & $\begin{array}{l}\text { Heparan sulfate } \\
\text { proteoglycan }\end{array}$ & $\begin{array}{l}\text { Low } \mathrm{pH} \text { for } \mathrm{MV} \\
\text { macropinosome }\end{array}$ & HeLa BS-C-1 & $\begin{array}{l}\text { Townsley et al. 2006; Mercer and Helenius } \\
\text { 2008; Schmidt et al. } 2011\end{array}$ \\
\hline Respiratory syncytial virus & $\begin{array}{l}\text { Paramyxoviridae } \\
\text { Enveloped } \\
\text { ss }(-) \text { RNA }\end{array}$ & $\begin{array}{l}\text { Heparan sulfate } \\
\text { proteoglycan } \\
\text { EGFR }\end{array}$ & $\begin{array}{l}\mathrm{pH} \text {-independent } \\
\text { macropinosome }\end{array}$ & $\mathrm{HeLa}$ & Krzyzaniak et al. 2013 \\
\hline Ebolavirus & $\begin{array}{l}\text { Filoviridae } \\
\text { Enveloped }\end{array}$ & $\begin{array}{l}\text { DC-SIGN and other } \\
\text { host lectins }\end{array}$ & $\begin{array}{l}\text { Cathepsins B and C } \\
\text { macropinosome }\end{array}$ & 293T Vero & $\begin{array}{l}\text { Chandran et al. 2005; Nanbo et al. 2010; } \\
\text { Saeed et al. } 2010\end{array}$ \\
\hline
\end{tabular}




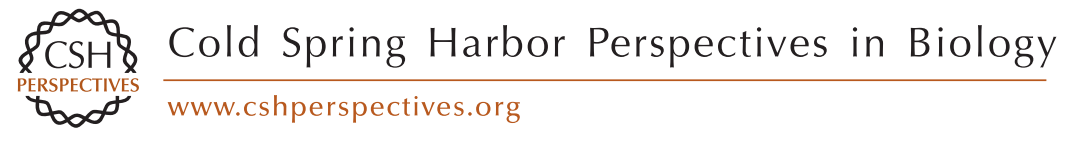

\begin{tabular}{|c|c|c|c|c|c|}
\hline Virus & Family & Receptor & Penetration & Cell type & References \\
\hline Kaposi sarcoma virus & $\begin{array}{l}\text { Herpesviridae } \\
\text { Enveloped } \\
\text { dsDNA }\end{array}$ & $\begin{array}{l}\text { Heparan sulfate } \\
\text { proteoglycan } \\
\text { Integrins } \alpha 3(\beta 1, \alpha \mathrm{V} \beta 3 \text {, } \\
\text { and } \alpha \mathrm{V} \beta 5)\end{array}$ & Macropinosomes & HMVEC-d & Valiya Veettil et al. 2010 \\
\hline \multicolumn{6}{|c|}{ Caveolar/lipid-mediated endocytosis } \\
\hline Simian virus 40 & $\begin{array}{l}\text { Polyomaviridae } \\
\text { Nonenveloped } \\
\text { dsDNA }\end{array}$ & GM1 ganglioside & $\begin{array}{l}\text { Endoplasmic } \\
\text { reticulum }\end{array}$ & $\begin{array}{l}\mathrm{CV}-1 \\
\mathrm{MEF} \mathrm{Cav}^{-/-}\end{array}$ & $\begin{array}{l}\text { Anderson et al. 1996; Stang et al. 1997; } \\
\text { Damm et al. } 2005\end{array}$ \\
\hline Polyomavirus (mouse) & $\begin{array}{l}\text { Polyomaviridae } \\
\text { Nonenveloped } \\
\text { dsDNA }\end{array}$ & $\begin{array}{l}\text { GD1A and GT1B } \\
\text { gangliosides }\end{array}$ & $\begin{array}{l}\text { Endoplasmic } \\
\text { reticulum }\end{array}$ & $\begin{array}{l}\text { NIH } 3 \text { T6 } \\
\text { NMuMG }\end{array}$ & Richterova et al. 2001; Tsai et al. 2003 \\
\hline \multicolumn{6}{|l|}{ Other mechanisms } \\
\hline $\begin{array}{l}\text { Papillomavirus } 16 \text { (human) } \\
\text { (HPV16) }\end{array}$ & $\begin{array}{l}\text { Papillomaviridae } \\
\text { Nonenveloped } \\
\text { dsDNA }\end{array}$ & $\begin{array}{l}\text { Heparan sulfate } \\
\text { proteoglycans }\end{array}$ & $\begin{array}{l}\text { Late endosome } \\
\text { macropinosome }\end{array}$ & HeLa HaCaT & Schelhaas et al. 2012 \\
\hline Polio virus & $\begin{array}{l}\text { Picornavirus } \\
\text { ss }(+) \text { RNA }\end{array}$ & Poliovirus receptor & $\begin{array}{l}\mathrm{pH} \text {-independent } \\
\text { early endosome }\end{array}$ & HeLa S3 & Brandenburg et al. 2007 \\
\hline $\begin{array}{l}\text { Lymphocytic } \\
\text { choriomeningitis virus } \\
\text { (LCMV) }\end{array}$ & $\begin{array}{l}\text { Lassaviridae } \\
\text { ss }(-) \text { RNA }\end{array}$ & $\alpha$-Dystroglycan & $\mathrm{pH}<6.3$ & Late endosome & $\begin{array}{l}\text { Di Simone et al. 1994; Quirin et al. 2008; } \\
\text { Rojek et al. } 2008\end{array}$ \\
\hline $\begin{array}{l}\text { Rhinovirus (HRV14) } \\
\text { Major group }\end{array}$ & $\begin{array}{l}\text { Picornaviridae } \\
\text { Nonenveloped } \\
\text { ss }(+) \text { RNA }\end{array}$ & ICAM-1 & $\begin{array}{l}\text { Low } \mathrm{pH} \\
\text { macropinosome? }\end{array}$ & $\begin{array}{l}\text { Rhabdomyosoma } \\
\text { cells }\end{array}$ & Khan et al. 2010 \\
\hline
\end{tabular}


face indentations. Ranging from proteoglycans to glycolipids and glycoproteins, the overall spectrum of cellular molecules identified as virus receptors is extremely broad (Helenius 2007). Some serve merely for attachment and concentration of viruses to the cell surface, whereas others have additional roles in signaling, endocytosis, and in the modification of the bound virus. In many cases, virus-cell interactions involve carbohydrates (Vasta 2009; Kamhi et al. 2013).

Although well-known endocytic receptors such as transferrin and LDL receptors occur in the list, the majority of virus receptors are not directly involved in the uptake of physiological ligands. By inducing clustering, viruses can generate a receptor-rich membrane microdomain that differs from the rest of the plasma membrane in protein and lipid composition (English and Hammer 2005; Lozach et al. 2011b). Such domains may serve as a platform for transmembrane signaling, for recruitment of cytoplasmic coats, and for assembly of endocytic machinery. In some instances, antibodies, complement factors, and other proteins in body fluids can play a bridging function between the virus and its receptors (Flipse et al. 2013). Receptors usually follow the virus into endocytic vesicles and into the cell. In addition to the virus particle, the endocytic "cargo" thus comprises a complex of receptors and lipids.

Importantly, virus-receptor interactions can result in alterations in the structure of viral proteins or in the virus particle as a whole (Lonberg-Holm and Philipson 1974; Raff et al. 2013). Simultaneous binding to a mobile and an immobile receptor was, for example, recently shown to subject adenovirus particles to forces that initiate uncoating by detaching some of the viral fibers (Burckhardt et al. 2011). A receptorinduced conformational change in the glycoprotein of HIV-1 is essential for triggering penetration by membrane fusion (Wilen et al. 2012).

In recent years, a new class of interaction partners on the cell surface has been recognized for viruses. These could be called "accessory factors" because they are primarily needed to activate signaling pathways and thus trigger endocytosis. They include receptor tyrosine ki- nases, phosphatidylserine (PS) receptors (TIM and TAM receptors), and integrins (Mercer and Helenius 2010; Morizono et al. 2011; Meertens et al. 2012). The interaction of viruses with these can be mediated by adaptors such as Gas6, a soluble protein that bridges between PS in the viral membrane and receptor tyrosine kinase Axl during activation of virus uptake by macropinocytosis (Morizono et al. 2011; Meertens et al. 2012). The physiological role of Gas6 is to serve as a soluble adaptor protein between PS in the membrane of cell remnants after apoptosis and Axl on the surface of cells (Lemke and Burstyn-Cohen 2010).

It is often observed that viruses use more than one type of receptor either in parallel, in sequence, or when interacting with different cell types. Rotaviruses, hepatitis $\mathrm{C}$ virus, HIV-1, and coxackie B virus are examples of viruses that interact sequentially with different cell-surface molecules (Coyne and Bergelson 2006; Lopez and Arias 2006). Other viruses such as many herpesviruses carry multiple receptor-binding glycoproteins with different specificity and can therefore enter different cell types (Eisenberg et al. 2012). That viruses can exploit multiple endocytic mechanisms and pathways is also clear. Herpes simplex virus I uses different pathways in different cell types (Campadelli-Fiume et al. 2012). Influenza Aviruses can, for example, use two or three different pathways (Matlin et al. 1981; Sieczkarski and Whittaker 2002; Lakadamyali et al. 2006; de Vries et al. 2011). Considering the underlying redundancy and complexity in virus-cell interactions, it is not surprising that the literature on the entry of many viruses is inconsistent and confusing.

\section{BACTERIAL BINDING TO HOST CELLS}

Endocytosis of bacteria starts by an irreversible interaction. Two main mechanisms may take place. In the first type, the adhesion between a bacterial ligand and a specific host surface receptor causes receptor clustering, the zippering of the plasma membrane around the bacterium, and the initiation of signaling events that culminate in entry. It is often difficult to separate the steps of adhesion and endocytosis during 
entry by this "zipper mechanism." In the second mechanism of bacterial endocytosis, the initial contact is a relatively transient event that essentially permits the direct delivery into the cell cytosol of active T3SS effectors that trigger cytoskeleton rearrangements and membrane remodeling, which lead to a macropinocytosislike event. This second way of entry is called "the trigger mechanism" (Fig 2; Table 2) (Cossart and Sansonetti 2004).

Binding to cells occurs via proteins called "adhesins" located either on the bacterial surface or at the tip of appendages called "pili" or "fimbriae," which form hair-like fibers that protrude from the surface. Because pili can be used for the transfer of genetic material during conjugation, the term "fimbriae" has in the past been used to describe those pili whose specific function is adhesion. However, the nomenclature remains fuzzy. Interestingly, some pili (e.g., type IV pili) not only mediate bacteria-host cell or bacteria-bacteria adhesion but also perform complex functions such as force-driven contraction providing bacteria with powerful tools to enhance their contact with target surfaces.

One of the best-characterized fimbriae is the pyelonephritis-associated (P) pilus, expressed by uropathogenic Escherichia coli that colonize the urinary tract and then infect the kidney. $\mathrm{P}$ pili bind through the PapG adhesin, located

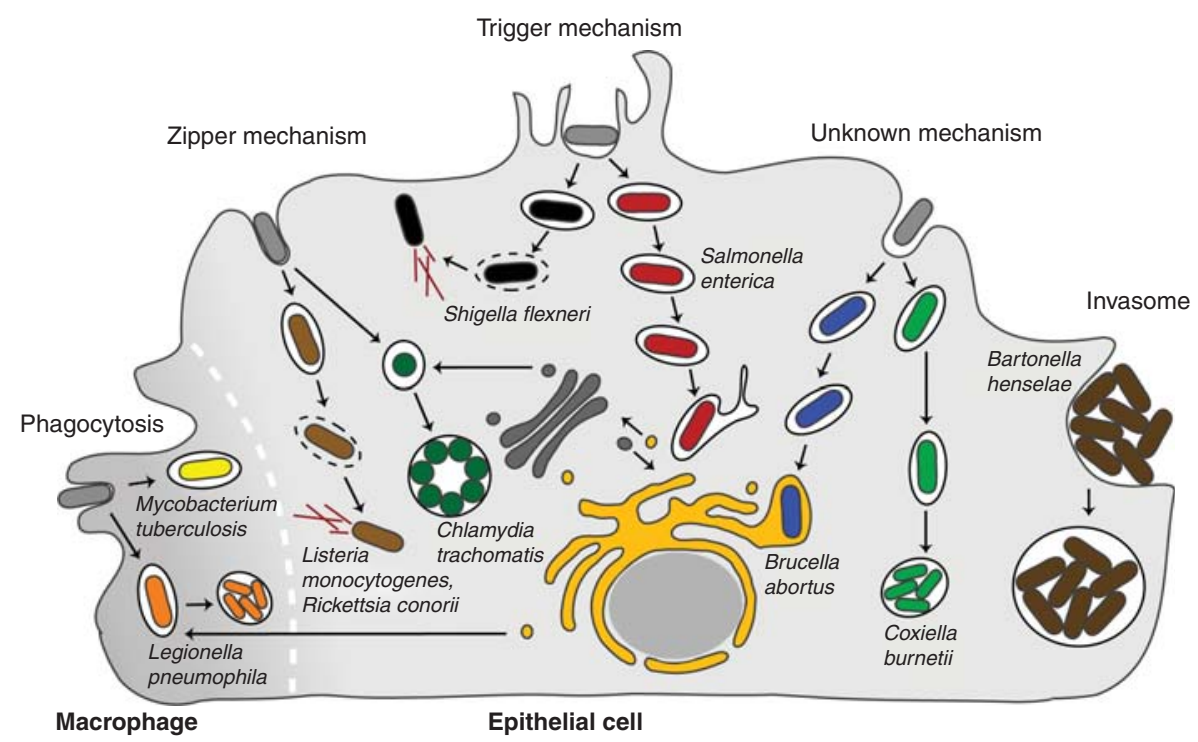

Figure 2. Pathways of endocytic entry by invasive bacteria. Schematic representation of bacterial endocytosis mechanisms and intravacuolar or intracytosolic lifestyles. In epithelial cells, Listeria enters via two internalins; it then resides transiently in a vacuole that is lysed allowing intracytosolic replication and actin-based motility. The obligate intracellular bacterium Chlamydia trachomatis resides in a vacuole that intercepts the pathway involved in the transport of shingomyelin from the Golgi apparatus to the plasma membrane. Shigella is first taken up by filopodia present on the surface of epithelial cells. The type 3SS then injects effectors that trigger entry, formation of the vacuole, and escape from this compartment, leading to intracytosolic replication and actin-based motility. Salmonella appears to enter after a "near-surface swimming" mechanism. The T3SS-1 (or SPI-1) triggers entry and formation of the replicative vacuole, which acquires markers of endosomes and lysosomes owing to the secretion of effectors of the T3SS-2 (or SPI-2). In some circumstances, Salmonella can reach the cytosol and rapidly replicate therein. The Brucella replicative vacuole is derived from the endocytic vacuole and matures in an ER-derived vacuole. Coxiella burnetii is the only bacterium that has evolved to survive and replicate in a lysosome-derived vacuole. Bartonella henselae can enter into endothelial cells as a single bacterium or as aroup, leading to the formation of an invasome. In macrophages, Legionella and Mycobacterium tuberculosis reside in a vacuole. The Legionella vacuole acquires markers of the ER. It is not the case for M. tuberculosis, which blocks the maturation of the internalization vacuole. 
Endocytosis of Viruses and Bacteria

Table 2. Examples of intracellular bacteria, their type of entry, and their intracellular lifestyle

\begin{tabular}{|c|c|c|c|c|}
\hline Bacteria & Bacterial factors & $\begin{array}{l}\text { Intracellular } \\
\text { lifestyles }\end{array}$ & Cell types & Reviews \\
\hline \multicolumn{5}{|l|}{ Zipper mechanism } \\
\hline Listeria monocytogenes & $\operatorname{In} 1 \mathrm{~A}, \operatorname{In} 1 \mathrm{~B}$ & Intracytosolic & Epithelial cells & Isberg and Barnes \\
\hline $\begin{array}{l}\text { Yersinia } \\
\quad \text { pseudotuberculosis }\end{array}$ & Invasin & $\begin{array}{l}\text { Intravacuolar, } \\
\text { pH } 6\end{array}$ & Epithelial cells & $\begin{array}{l}\text { 2001; Cossart } \\
2011\end{array}$ \\
\hline \multicolumn{5}{|l|}{ Trigger mechanism } \\
\hline Shigella flexneri & Type III secretion system & Intracytosolic & Epithelial cells & Patel and Galan \\
\hline $\begin{array}{l}\text { Salmonella } \\
\quad \text { typhimurium }\end{array}$ & Type III secretion system & $\begin{array}{l}\text { Intravacuolar, } \\
\text { pH } 5\end{array}$ & Epithelial cells & $\begin{array}{l}\text { 2005; Carayol and } \\
\text { Tran Van Nhieu } \\
2013\end{array}$ \\
\hline \multicolumn{5}{|l|}{ Invasome } \\
\hline Bartonella & Type IV secretion system & $\begin{array}{l}\text { Intravacuolar, } \\
\mathrm{pH}>6\end{array}$ & Endothelial cells & $\begin{array}{l}\text { Eicher and Dehio } \\
\quad 2012\end{array}$ \\
\hline \multicolumn{5}{|l|}{ Intravacuolar bacteria } \\
\hline Salmonella & Type III secretion system & $\begin{array}{l}\text { Intravacuolar, } \\
\text { pH } 5\end{array}$ & Epithelial cells & $\begin{array}{l}\text { Figueira and Holden } \\
\quad 2012\end{array}$ \\
\hline Chlamydia & Type III secretion system & $\begin{array}{c}\text { Intravacuolar, } \\
\mathrm{pH}=7.25\end{array}$ & Epithelial cells & Bastidas et al. 2013 \\
\hline Legionella & Type IV secretion system & $\begin{array}{l}\text { Intravacuolar, } \\
\text { pH } 6\end{array}$ & Macrophages & $\begin{array}{l}\text { Isberg et al. 2009; } \\
\text { Hubber and Roy } \\
2010\end{array}$ \\
\hline Brucella & Type IV secretion system & $\begin{array}{l}\text { Intravacuolar, } \\
\text { pH } 4\end{array}$ & Epithelial cells & $\begin{array}{l}\text { von Bargen et al. } \\
2012\end{array}$ \\
\hline Coxiella & Type IV secretion system & $\begin{array}{l}\text { Intravacuolar, } \\
\text { pH } 5\end{array}$ & Epithelial cells & $\begin{array}{l}\text { Voth and Heinzen } \\
2007\end{array}$ \\
\hline $\begin{array}{c}\text { Mycobacterium } \\
\text { tuberculosis }\end{array}$ & Type VII secretion system & $\begin{array}{l}\text { Intravacuolar, } \\
\text { pH } 6.4\end{array}$ & Macrophages & $\begin{array}{l}\text { Soldati and Neyrolles } \\
\text { 2012; Russell } 2013\end{array}$ \\
\hline
\end{tabular}

at the tip of the complex pilus rod, to the $\alpha$ D-galactopyranosyl(1-4)- $\beta$-D-galactopyranoside moiety of glycolipids of upper urinary tract cells (Waksman and Hultgren 2009). In addition, the pili mediate the generation of biofilm-like structures on and inside host cells, contributing to the persistence of the bacteria in the bladder.

Type IV pili are essentially composed of a homopolymer of a single pilin subunit such as pilA in Pseudomonas aeruginosa, PilE in Neisseria spp., or TcpA in Vibrio cholerae (Craig et al. 2004). As stated above, type IV pili have been implicated in other functions including biofilm formation. Interestingly, a posttranslational modification of the Neisseria meningitidis pilin subunit has been shown to change the conformation of the pilin and lead to loss of interbacterial interactions at sites of adhesion leading to Neisseria dissemination through epithelial cells and bacterial access to blood vessels (ChamotRooke et al. 2011). Recently a novel type of pilus made of a single type of pilin subunit-polymerized via sortases that covalently link the subunits together-was identified in clinically important pathogens such as Streptococci and Pneumococci and shown to be critical for infection paving the way to new vaccine strategies (Ton-That et al. 2004; Dramsi et al. 2006; Falker et al. 2008).

A variety of nonpolymeric adhesins have been reported that mediate bacterial adhesion to host surface components, in particular, to host membrane adhesion receptors such as integrins, cadherins, selectins, and CEACAMs. In the case of invasive bacteria, these adhesins often serve as invasion proteins, that is, proteins that mediate the endocytosis process itself (Fig. 2). It is the case for Internalin (InlA) of 
P. Cossart and A. Helenius

Listeria monocytogenes (Gaillard et al. 1991) or invasin of Yersinia pseudotuberculosis (Isberg et al. 1987) (see below).

A unique situation has been described in the case of enteropathogenic E. coli. These bacteria inject a type III effector called Tir into mammalian cells. Tir inserts in the plasma membrane and acts as a receptor for the bacterial protein intimin (Rosenshine et al. 1996; Kenny et al. 1997). Tir also mediates the recruitment of several proteins including clathrin, dynamin, and Dab2 before the recruitment of components of the actin cytoskeleton and, in particular, the Arp2/3 complex, which mediates the polymerization of actin filaments (Unsworth et al. 2007; Veiga et al. 2007; Bonazzi et al. 2011). The result is the formation of a pedestal on which bacteria are located and tightly adhere. Hence, tight adherence in the presence of typical endocytic molecules such as clathrin or dynamin does not necessarily lead to endocytosis.

\section{ENDOCYTOSIS OF VIRUSES}

The rate and efficiency of viral endocytosis are variable. After binding to the cell surface, internalization can occur with a half-time as short as a few minutes or as long as several hours. Uptake is usually nonsynchronous, but in the end quite efficient. Viruses exploit the capacities of the host cell by making use of different cellular endocytosis mechanisms, which they can activate and modify for their specific purposes when needed (Fig. 1). Although the dependence of viruses on cellular processes in all stages of entry and uncoating makes possible the stripped-down economy in the structure of viral particles, it also means that viruses and their components must interact directly or indirectly with a multitude of cellular factors.

\section{Clathrin-Mediated Endocytosis}

Clathrin-mediated endocytosis (CME) is probably the most common mechanism for endocytosis of small and medium-size viruses (Figs. 1 and 3; Table 1) (Dales 1978; Helenius et al. 1980; Matlin et al. 1981; DeTulleo and Kirchhausen 1998; Sun et al. 2013). Time-lapse movies

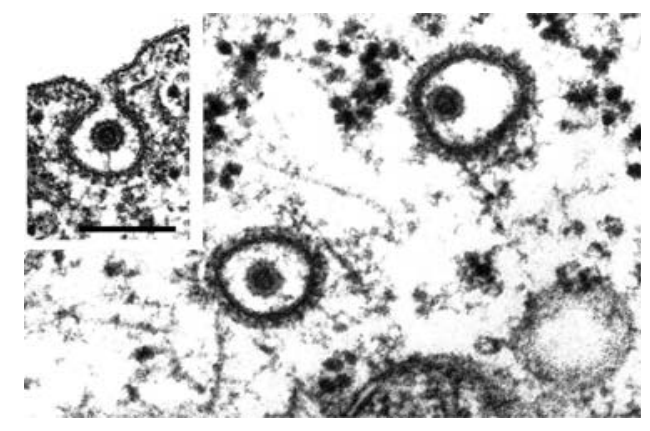

Figure 3. Semliki Forest virus is internalized by clathrin-coated vesicles. After attaching to the surface of BHK-21 cells, this simple, enveloped RNAvirus of the $\operatorname{toga}(\alpha)$ virus family is rapidly endocytosed by clathrin-mediated endocytosis, and penetration occurs in early endosomes (Helenius et al. 1980). Scale bar, $200 \mathrm{~nm}$.

show two general behaviors. After a period of lateral movement along the membrane, some particles diffuse into preexisting clathrin-coated areas, and others induce clathrin assembly at the site of binding (Ehrlich et al. 2004; Rust et al. 2004; van der Schaar et al. 2008; Johannsdottir et al. 2009). In the latter case, the assembly of a clathrin coat takes somewhat longer than for clathrin pit formation during uptake of endogenous protein ligands (1-6 min). The coated vesicles pinch off with one or more viruses. The coat dissociates within 5-20 sec, and the viruses are delivered within minutes to early endosomes in the periphery of the cell. Like CME of physiological cargo, uptake of viruses depends on $\mathrm{PI}(4,5) \mathrm{P}_{2}$ and dynamin- 2 and is usually inhibited by chlorpromazine, an inhibitor of CME (Wang et al. 1993; Sieczkarski and Whittaker 2002).

Vesicular stomatitis virus (VSV) belongs to the viruses that use CME for productive infection (Matlin et al. 1982). In human cells, the receptor for VSV was recently identified as the LDL receptor and its family members (Finkelshtein et al. 2013). Light microscopy in live cells combined with single-particle tracking shows that the clathrin coat is recruited to sites of VSV binding (Cureton et al. 2009; Johannsdottir et al. 2009). Because of the bullet shape and large size of VSV particles, the clathrin vesicles 
form slowly, they deviate from the round shape, and some carry only a partial clathrin coat $(\mathrm{Cu}-$ reton et al. 2009). Although VSV endocytosis is dependent on plasma membrane $\operatorname{PI}(4,5) \mathrm{P}_{2}$, dynamin, and actin, it is unclear whether AP2 is the adaptor protein required for endocytosis and infection (Cureton et al. 2009; Johannsdottir et al. 2009; Vazquez-Calvo et al. 2012b).

A general lesson from the observations with VSV and other viruses is that although the viruses differ in size, they have evolved to use CME very efficiently. They can induce the formation of clathrin-coated vesicles (CCVs) locally, and they can adapt the size and shape of the clathrincoated pits (CCPs) for their needs. It will be interesting to determine how VSV and other viruses guide and regulate the coat assembly process.

\section{Clathrin- and Caveolin-Independent Endocytosis}

The existence of a clathrin-, caveolin-, and dynamin-independent pathway for virus endocytosis was first described for members of the polyomaviruses: mouse polyoma virus, and SV40 (Gilbert and Benjamin 2000; Damm et al. 2005). These are small nonenveloped DNA viruses (diameter $50 \mathrm{~nm}$ ) that replicate in the nucleus of host cells. The VP1 proteins that form the icosahedral viral coat bind to the sialic-acid-containing carbohydrate moiety of specific gangliosides that serve as cell-surface receptors (Tsai et al. 2003). Present as 72 homopentamers, VP1 constitutes the main building block in the capsid shell (Stehle et al. 1996).

By binding to multiple GM1 molecules, SV40 actively generates membrane curvature (Ewers et al. 2010). In a process that in EM sections looks as if the virus particle would be budding into the cell, the PM wraps itself tightly around the virus particle (Fig. 4F). The same can be seen when viruses are added to giant unilamellar liposomes containing GM1 with long acyl chains. When many viruses are present, long, narrow, tight-fitting, tubular invaginations with multiple viruses can form in the PM of cells and in liposomes. Interestingly, pit and tube formation does not require the whole

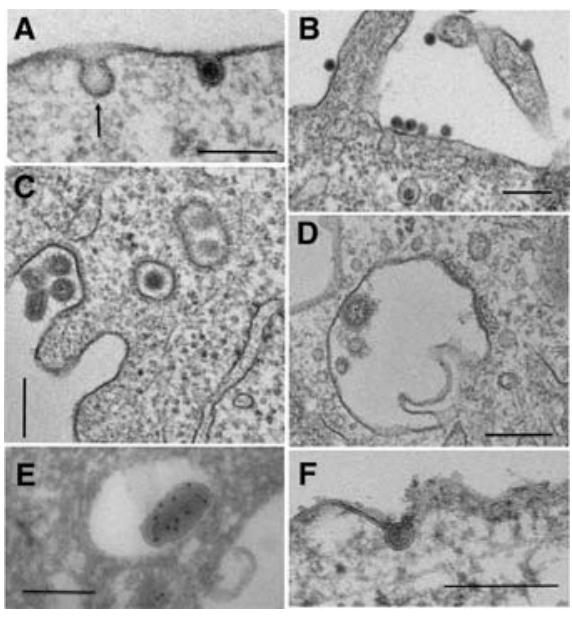

Figure 4. Endocytosis of enveloped and nonenveloped viruses. These electron micrographs show viruses from different families during endocytic entry. (A) Bound to its ganglioside receptors (GDla and GT1b), an incoming mouse polyoma virus particle is seen in a tight-fitting indentation of the plasma membrane of a $3 \mathrm{~T} 6$ cell. Although viruses of the polyoma virus family can also use caveolae (see arrow) for entry, this particle is most likely making use of a clathrin- and caveolin-independent mechanism used by these viruses. $(B)$ Human papilloma virus 16 enters HeLa cells via a macropinocytosis-like mechanism that involves binding to filopodia, surfing along filopodia to the cell body, and activation of an endocytic process independent of clathrin and caveolin (Schelhaas et al. 2008, 2012). (C) Vesicular stomatitis virus is internalized by clathrin-coated vesicles (Matlin et al. 1982). (D) An influenza A virus particle is seen in an early endosome after endocytic internalization (Matlin et al. 1981). (E) In this cryoEM image, a vaccinia virus particle (a poxvirus) is seen in a macropinocytic vacuole after endocytosis in a HeLa cell. The particle is labeled with immunogold against the A5 core protein. $(F)$ The contact between an SV40 particle and the plasma membrane is very tight during the clathrin- and caveolin-independent entry process. The virus seems to bud into the cell. Scale bars, $200 \mathrm{~nm}$. The images are by Roberta Mancini $(A-D)$ and Christopher Bleck $(E)$.

virus; isolated VP1 homopentamers are sufficient.

For the fission reaction that detaches the virus-containing indentations, the virus alone is not sufficient. Energy in the form ATP is required, as well as cellular tyrosine kinases, cho- 
lesterol, and a change in actin dynamics. Contrary to CCVs, vesicle fission is independent of dynamin (Damm et al. 2005). The viruscontaining vesicles formed are delivered to early endosomes, and the virus is eventually transported via late endosomes to the ER (Fig. 1) (Qian et al. 2009; Engel et al. 2011). It is noteworthy that a similar mechanism is used by pentameric, bacterial toxins (cholera and Shiga) that bind to glycolipids (Römer et al. 2010). In all these cases, the receptors are glycosphingolipid molecules concentrated in lipid rafts. They differ from most other receptors in that they do not span the bilayer.

\section{Caveolar Endocytosis}

Caveolar endocytosis has been proposed for a variety of viruses. One of the problems in assigning viruses to this pathway is that the endocytic role of caveolae in cell life is still poorly defined. No single characteristic such as cholesterol dependence alone is sufficient as a criterion to define this pathway. Although much less dynamic than CCVs, it is clear, however, that a fraction of the caveolae is mobile and can undergo endocytosis especially when activated by a ligand (Kirkham and Parton 2005; Pelkmans and Zerial 2005; Tagawa et al. 2005).

The best studied among the viral candidates for caveolar uptake is SV40. Morphological evidence from several laboratories using immune-electron and immunofluorescence microscopy shows colocalization of the viruses and caveolin-1 in plasma membrane spots and pits (Anderson et al. 1996; Stang et al. 1997; Pelkmans et al. 2001). Addition of SV40 to cells causes a dramatic, tyrosine-phosphorylationdependent elevation in caveolar vesicle formation and caveolar vesicle motility (Tagawa et al. 2005). shRNA- and siRNA-mediated depletion of caveolin-1 results in a decrease in SV40 endocytosis and infection (Pelkmans et al. 2004; Stergiou et al. 2013). Recently, it was shown that depletion of EHD2 (a peripheral caveolar ATPase) leads to a dramatic increase in caveolar vesicle trafficking and increases the efficiency of SV40 infection (Stoeber et al. 2012; M Stoeber, G Balustreri, and A Helenius, unpubl.).
Thus, in summary, it seems that SV40 can make use of two parallel endocytic mechanisms. One corresponds to the caveolar pathway and relies on caveolin-1. The other is caveolin independent, with the virus particle serving as the curvature-generating principle. To what extent viruses other than SV40 can use these pathways is not clear. There are reports suggesting that other polyomaviruses such as BK virus and mouse polyoma virus may also exploit caveolae (Richterova et al. 2001; Neu et al. 2009).

\section{Virus-Triggered Macropinocytosis}

Macropinocytosis offers incoming viruses an altogether different type of endocytic experience (Fig. 1). Transiently triggered by external ligands such as growth factors and PS-containing particles, this mechanism is known to induce internalization of fluid, membrane, and whatever happens to be associated with the membrane such as viruses (Swanson and Watts 1995). The process is important for the clearing of cell remnants after apoptotic cell death. The PS exposed on cell remnants constitutes an "eatme" signal that secures efficient uptake and degradation of cellular garbage without triggering an inflammatory response (Hoffmann et al. 2001).

The key events in macropinocytosis include the activation of receptor molecules such as receptor tyrosine kinases, integrins, and PS receptors (Swanson and Watts 1995). This triggers downstream signaling cascades resulting in transient, global changes in actin dynamics that lead to cell-wide plasma membrane ruffling in the form of filopodia, lamellopodia, circular ruffles, or blebs. Large, uncoated vacuoles (macropinosomes) are formed. After moving deeper into the cytoplasm, these usually end up fusing with late endosomes or lysosomes. Important distinguishing features for macropinocytosis include activation Rho GTPases (Racl and/or Cdc42), myosins, and kinases such as PAK1, PI3 kinase, and PKC. The process is sensitive to inhibitors of $\mathrm{Na}^{+} / \mathrm{H}^{+}$exchangers. Because there are many variations of the process, macropinocytosis must be viewed as a collective term for an assortment of related mechanisms. 
Macropinocytosis plays a role in the infection of viruses of different families including large viruses such as pox-, filo-, paramyxo, and herpesviruses (Lim and Gleeson 2011; Mercer and Helenius 2012). Some smaller enveloped and nonenveloped viruses such as influenza A virus seem to use pathways that share many properties with macropinocytosis (Khan et al. 2010; de Vries et al. 2011). By exposing PS in their envelope, vaccinia and some other enveloped viruses make use of "apoptotic mimicry" (Mercer and Helenius 2008). The emerging role of PS receptors of the TIM and TAM families and adaptors such as Gas6 in this process was already discussed above. Epidermal growth factor receptor (EGFR) and other growth factor receptors are often activated and essential as accessory factors in infectivity (Eierhoff et al. 2010; Mercer et al. 2010a; Krzyzaniak et al. 2013).

\section{Other Endocytic Pathways for Virus Internalization}

There are viruses for which endocytic entry does not fall into the categories listed above (Table 1). One of them is human papilloma virus 16 (HPV-16), which in HeLa and HaCaT cells uses a mechanism with similarities to macropinocytosis (Schelhaas et al. 2008). However, the vesicles are small, Rho GTPases are not activated, and there is no elevation in fluid uptake. Some of these characteristics are shared by human rhinovirus 14 and one of the alternate pathways described for influenza A virus (Matlin et al. 1981; Rust et al. 2004; Khan et al. 2010; de Vries et al. 2011). In addition, two Old World arenaviruses, LCMV and Lassa virus, enter by a clathrin-, caveolin-, and dynamin-independent pathway via multivesicular bodies bypassing early endosomes (Quirin et al. 2008; Kunz 2009). In the case of Acanthamoeba polyphaga mimivirus, a giant enveloped virus (750 $\mathrm{nm}$ in diameter) that uses amoeba as a host, uptake into human macrophages seems to involve a phagocytosis-like mechanism (Ghigo et al. 2008). This uptake process resembles the phagocytosis of bacteria.

Of the various endocytic mechanisms described in mammalian cells, the CLIC/GEEC,
IL2, flotillin, and CIE/Arf 6 pathways do not seem to support virus entry (Lamaze et al. 2001; Mayor and Pagano 2007; Donaldson et al. 2009; see also Mayor et al. 2014). However, because virus entry studies and the classification of endocytic mechanisms are not always straightforward, the situation may change. Viruses may, in fact, provide one of the most informative systems for further classification of endocytic processes.

\section{ENDOCYTOSIS OF BACTERIA}

The rate and efficiency of entry of bacteria into cells vary greatly with the cell type and other parameters such as the temperature or the growth phase at which bacteria have been harvested (Fig. 5).

The Zipper Mechanism: A Clathrin- and ActinMediated Internalization Process

The hallmarks of the zipper mechanism are a dedicated bacterial surface protein or component that interacts directly with a host cell receptor, thereby inducing a series of signaling events that culminates in endocytosis. The actin cytoskeleton and its dynamics as well as the membrane composition and its plasticity are critical elements (Pizarro-Cerda and Cossart 2004, 2006; Cossart and Roy 2010). The bacterial proteins involved in entry often mimic endogenous ligands and exploit the properties of their receptors maximally. Alternatively, bacteria can (like viruses described above) interact with components that act as a bridge to a cellsurface receptor. It is clear that the affinity of the ligand and its density on the bacterial surface critically control the efficiency of the entry process. More recently, the CME machinery has been shown to be involved in early steps after initial contact between the incoming microbe and the receptor before the cytoskeleton rearrangements (Boleti et al. 1999; Veiga and Cossart 2005; Veiga et al. 2007; Eto et al. 2008; Pizarro-Cerda et al. 2010; Bonazzi et al. 2011).

Listeria monocytogenes is the prototype of a bacterium entering by the zipper mechanism (Pizarro-Cerda et al. 2012). It expresses two 
P. Cossart and A. Helenius
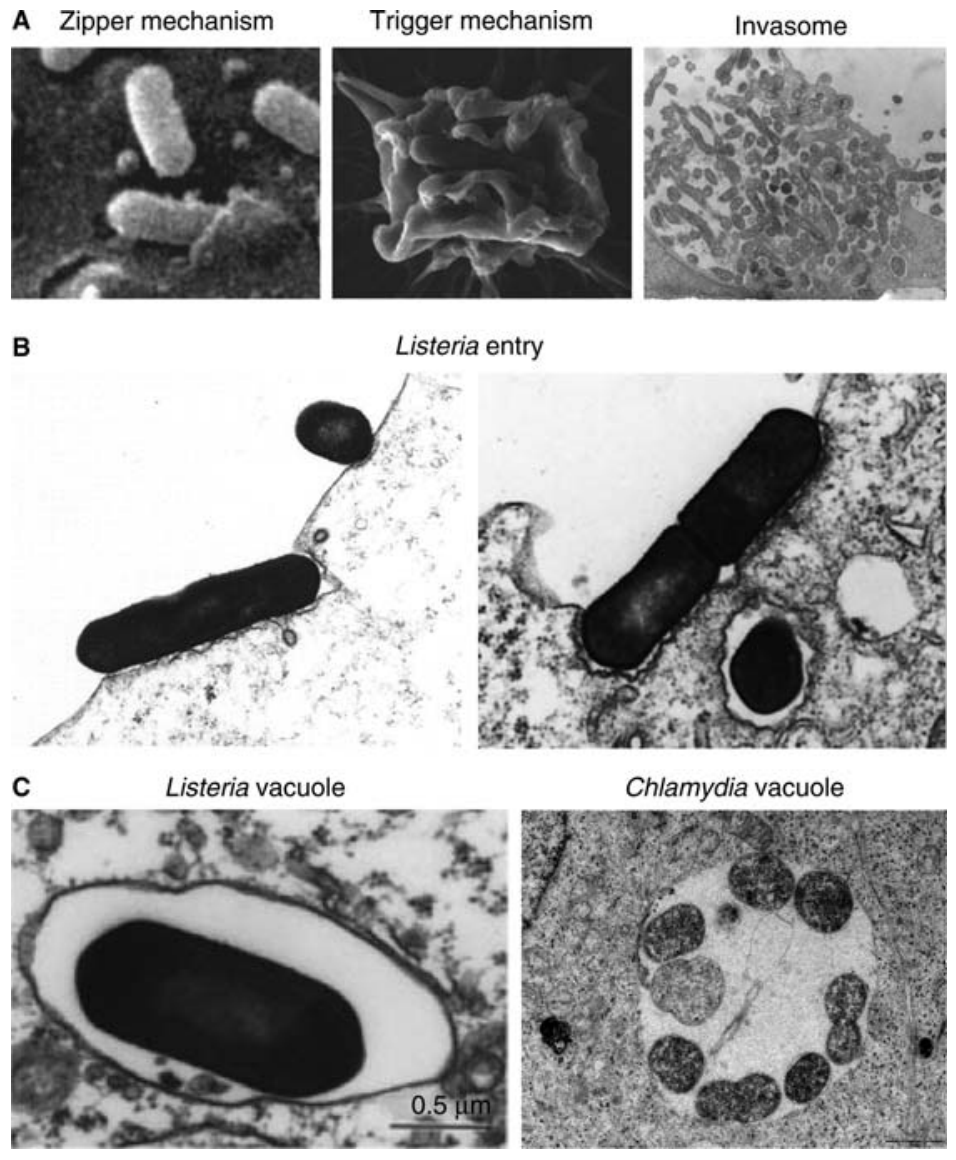

Figure 5. Endocytosis of bacteria. These electron micrographs show various phases of bacterial endocytosis into mammalian cells. $(A$, left) Binding of Listeria entering into cells. Two coated pits are detectable on this cross section. The tight apposition of the membrane illustrates what is meant by the zipper mechanism. ( $A$, middle micrograph) A Shigella entering into a cell and the huge membrane ruffles that engulf the bacterium. This micrograph illustrates the trigger mechanism. (A, right) Bartonella henselae enter as a group into an endothelial cell. (B) Listeria is entering into the cell and the clathrin coat is visible as a thickening of the plasma membrane underneath the bacterium. ( $C$, left) Listeria is present in a membrane-bound vacuole. $(C$, right) Chlamydia vacuole full of bacteria that have replicated.

proteins involved in entry. The first, Internalin (InlA), is a surface protein that interacts with E-cadherin, a cell-cell adhesion molecule expressed only in some epithelial cells (Mengaud et al. 1996). For entry into most cell types, Listeria uses a second invasin, the InlB protein, which activates the receptor tyrosine kinase Met, the hepatocyte growth factor receptor that is expressed on all cells of epithelial origin (Shen et al. 2000; Bierne and Cossart 2002).

Integrity of the membrane and its lipid rafts is critical for the initial clustering of E-cadherin when bacteria enter by the InlA pathway. In contrast, for the InlB pathway, the integrity of lipid rafts is critical for the correct localization of the phosphoinositides produced in the plasma membrane by PI3 kinase, which is recruited to the receptor activated upon bacterial entry (Seveau et al. 2004, 2007).

Investigations of Listeria endocytosis in cells that do not express E-cadherin have shown that InlB mimics HGF and first induces the autophosphorylation of Met (Shen et al. 2000). This, in turn, leads to the recruitment of Gab1, 
Cbl, and Shc (Ireton et al. 1999; Shen et al. 2000). The ubiquitin ligase Cbl triggers the ubiquitination of Met as a prelude for the recruitment of the clathrin adaptor Dab2 and that of the clathrin heavy and light chains (Veiga and Cossart 2005). Src-mediated phosphorylation of the clathrin heavy chain is critical for the whole process (Veiga et al. 2007; Bonazzi et al. 2011). Strikingly, Hip1R, which interacts with the clathrin light chain and actin filaments, is then recruited followed by myosin VI, which interacts with Hip1R and actin. Because myosin VI has the capacity to move toward the minus end of actin filaments, it probably then pulls the bacteria toward the interior of the cell. Dynamin is also recruited at the bacterial entry site, as well as cortactin. A first wave of actin polymerization may thus take place following the interaction of cortactin with the Arp2/3 complex. A second wave of actin rearrangements is then triggered more classically by the Gab1-mediated recruitment of PI3 kinase (Ireton et al. 1996) and the activation of small G proteins (Pizarro-Cerda et al. 2012). Note that actin rearrangements are finally down-regulated by the recruitment of proteins such as cofilin (Bierne et al. 2001) or OCRL a phosphatidyl inositol-5-phosphatase that dephosphorylates $\mathrm{PI}(4,5) \mathrm{P}_{2}$ and $\mathrm{PI}(3,4,5)$ $\mathrm{P}_{3}$ (Kuhbacher et al. 2012).

Strikingly, although immunofluorescence data clearly show clathrin recruitment at the entry site (Veiga and Cossart 2005; Veiga et al. 2007), ultrastructural analysis by electron microscopy of cells infected with Listeria shows the presence of clathrin on membranous invaginations, as isolated clathrin-coated pits (Bonazzi et al. 2011). Clathrin-coated vesicles are not seen. That clathrin depletion prevents actin recruitment suggests that coated pits serve as a platform for cytoskeletal arrangements (Lecuit et al. 2000; Pizarro-Cerda et al. 2010; see also Brodsky et al. 2014).

In cells that express E-cadherin, Listeria exploits the normal properties of this transmembrane protein and induces its interaction with $\alpha$ and $\beta$ catenins to trigger signaling events that culminate in Arp2/3-dependent actin polymerization events (Sousa et al. 2007). Interestingly like Met (see above) and many other receptors,
E-cadherin undergoes several posttranslational modifications upon activation including phosphorylation and ubiquitination (Bonazzi et al. 2008). Ubiquitination is mediated by the E-cadherin-specific ubiquitin ligase Hakai and allows the recruitment of clathrin and other components of the clathrin-mediated endocytosis machinery upstream of actin rearrangements (Bonazzi et al. 2008). Interestingly, colocalization of caveolin at the site of the InlA E-cadherin entry site and depletion experiments show that caveolin also participates in entry. Listeria entry is thus a complex process implicating the clathrin-mediated endocytosis machinery, the actin cytoskeleton as in classical phagocytosis, and caveolae (Pizarro-Cerda et al. 2012).

Entry of Yersinia pseudotuberculosis into cells resembles that of Listeria (Wong and Isberg 2005). An outer membrane protein called invasin interacts with $\beta 1$-integrins, that is, proteins that are normally implicated in adherence of cells to the extracellular matrix (Van Nhieu and Isberg 1991). Unlike fibronectin, invasin does not possess an RGD motif, but has a domain structurally similar. Invasin has a higher affinity than fibronectin for integrins. It induces integrin clustering and efficient downstream signaling. The cytoplasmic tail of the $\beta 1$ chain, which normally interacts with the cytoskeleton in focal complexes of adhesion plaques, is critical for entry, but, surprisingly, alterations in this domain that impair interaction with the cytoskeleton increase internalization (Van Nhieu et al. 1996). Thus, a lower affinity of the integrin for the cytoskeleton could allow higher mobility of the receptors in the membrane. Activation of integrins leads to the activation of the Arp2/3 complex and to the actin rearrangements necessary for uptake. The local concentration of $\mathrm{PI}(4,5) \mathrm{P}_{2}$ is critical for entry, and Arf6 may have a role in activation of PIP5 kinase, the control of cytoskeleton rearrangements and membrane traffic involved in the closure of the phagocytic cup (Wong and Isberg 2003). The analysis of Yersinia entry has frequently involved the use of E. coli-expressing invasin as a surrogate. This strain has recently been used to show that (as for Listeria) the clathrin-mediated endocytosis machinery is critical for bacterial en- 
try (Veiga et al. 2007). However, this has not been studied in detail yet.

Several other bacteria such as some Streptococci and also Staphylococcus aureus use integrins for their uptake (Ozeri et al. 2001; Kreikemeyer et al. 2004). However, they express a variety of fibronectin-binding proteins and use a bridging mechanism. As for Listeria, uptake of these bacteria requires components of the clathrin-mediated endocytic pathway.

To enter cells, the Gram-negative bacterium Chlamydia makes use of at least one early-secreted type III secretion system (T3SS) effector called TARP, a protein that nucleates actin polymerization directly (Jewett et al. 2010). In addition to TARP, entry requires the concerted activation of growth factor receptors, cytoplasmic kinases, and small GTPases to remodel the actin cytoskeleton (Lane et al. 2008). Additional host factors include clathrin and cholesterolrich microdomains (Boleti et al. 1999; Gabel et al. 2004).

The Trigger Mechanism: A MacropinocytosisRelated Process

Shigella and Salmonella are two bacteria that use the trigger mechanism to enter cells (Tran Van Nhieu et al. 2000; Patel and Galan 2005; Carayol and Tran Van Nhieu 2013). The hallmark of this mechanism is the formation of huge, actin-rich membrane ruffles triggered by a signaling cascade that induces localized transient changes in actin dynamics. It is triggered by the translocation of T3SS effectors into the host cytosol. In Salmonella, the secretion system involved in entry is encoded by a chromosomal pathogenicity island (PAI). In Shigella, the PAI is carried by a plasmid. These PAIs encode the structural components for the T3SS and some of their dedicated effectors.

For many years, the nature of the initial contact between Shigella and cells remained elusive. More recently, it was shown that upon challenge with epithelial cells, Shigella establish contacts with filopodial-like extensions, which then retract to bring bacteria into contact with the cell body, where invasion occurs (Romero et al. 2011). Filopodia are cell-surface sensory organ- elles implicated in adhesive processes, including the formation of intercellular junctions. They are not induced by bacterial contact. Time-lapse video microscopy showed that bacterial capture by filopodia can be inhibited by antibodies against IpaB and $\mathrm{IpaD}$, two proteins that are located at the tip of the T3SS, indicating that contact likely occurs between a cell-surface receptor present at the filopodial tip and the T3SS tip complex (Carayol and Tran Van Nhieu 2013).

Upon cell contact, IpaB and IpaC insert into the host cell plasma membrane to form a translocon complex that allows injection of T3SS effectors. These induce localized membrane ruffling by polymerization of cortical actin. Invasion requires the concerted action of several T3SS effectors to activate tyrosine kinases and Rho GTPases. At least two of the effectors (IpgB1 and B2) act as GEFs for Cdc42, Rac, and Rho, respectively (Bulgin et al. 2010). It is possible that these activities synergize for efficient actin polymerization. In addition to $\mathrm{IpaC}$, IpgB1, and IpgB2, the IpaA and IpgD type III effectors have been implicated in Shigella invasion. IpgD may promote invasion through its $\mathrm{PI}(4,5) \mathrm{P}_{2}$ phosphatase activity (Niebuhr et al. 2002), which might help to loosen the connection between cortical actin and the membrane, thereby affecting actin dynamics at bacterial invasion sites. IpaA induces actin depolymerization at subsequent stages of the entry process.

Filopodial capture might allow bacteria to target specific sites of the epithelium (Romero et al. 2011). Indeed, Shigella invasion occurs mainly at multicellular junctions in the apical surface of polarized intestinal cells. These correspond to the intersection between several cells. Interestingly, tricellulin (a protein required for the integrity of multicellular junctions) is essential for cell-to-cell spreading of Shigella, a process involving components of the clathrin-mediated endocytosis pathway (Fukumatsu et al. 2012).

In contrast to Shigella, which is nonadhesive and nonmotile and sampled by the finger-like extensions of the cell surface, Salmonella is a motile bacterium. It can, moreover, adhere to the cell via the SPI-1 T3SS (Salmonella has a 
second T3SS involved in intracellular replication; see below) and via the fimbrial adhesin Fim. In HeLa cells, the binding by Fim is reversible, whereas that mediated by the SPI-1 T3SS is irreversible (Misselwitz et al. 2011, 2012). It has been proposed that on a cell surface, "near-surface swimming" of Salmonella mediated by the flagellar motility allows landing on a surface, followed by Fim-mediated reversible binding with further "near-surface swimming" or docking mediated by the SPI-1 T3SS. This step commits Salmonella to invasion via the translocation of the effectors SopE, SopE2 (two GEFS for Rac and CDC42), SopB [a T3SS effector similar to $\operatorname{IpgD}$ with $\mathrm{PI}(4,5) \mathrm{P}_{2}$ phosphatase activity that activates RhoG], SipC (which can nucleate and bundle actin filaments directly), and SipA (which also participates in actin polymerization) (Cain et al. 2008; Humphreys et al. 2012). The Arp2/3 complex activation via SopE/E2/B, Rac1 and RhoG, WAVE, and WASH is involved but not essential for Salmonella invasion, which is also mediated by a SopB, Rho, RHO kinase, myosin-IIA/B-dependent, actomyosin-mediated contractility (Hanisch et al. 2011).

Interestingly, the "zipper" versus "trigger" entry mechanisms should not strictly be attributed to one given species. Indeed, a recent report shows that Salmonella can also enter cells by a zipper-like mechanism mediated by an outer membrane protein named Rck and a signaling pathway that ressembles that of Listeria (Mijouin et al. 2012).

\section{The Invasome of Bartonella: Entry as a Group}

Bartonella henselae is a Gram-negative bacterium that specifically colonizes the endothelium (Dehio 2004). It invades and colonizes primary human umbilical vein endothelial cells (HUVEC) by two distinct routes, either as individual bacteria through a "classical" endocytic pathway (which to our knowledge up to now has not been investigated) or as bacterial aggregates that are formed on the cellular surface, followed by their engulfment and internalization via the invasome structure (Dehio et al. 1997; Eicher and Dehio 2012). Attachment to nucleated cells is mediated by nonfimbrial outer membrane adhesion protein belonging to the type $\mathrm{V}$ secretion systems (T5SS), for example, trimer autotransporters, including BadA (Bartonella adhesin A) and Vomps (variably expressed outer membrane proteins). Invasome formation and internalization is an actin- and $\beta 1$-integrindependent process. The massive cytoskeletal rearrangements resulting in invasome-mediated uptake of bacterial aggregates are entirely dependent on the VirB type IV secretion system, but the specific effectors involved are unknown. Interestingly, Bartonella also invades erythrocytes, in this case, with an essential role for the invasion-associated locus proteins (IalA and IalB). This entry probably uses a novel mechanism that deserves investigation.

\section{VIRUSES IN THE ENDOSOME NETWORK}

After endocytic uptake, the incoming pathogens enter a complex network of heterogeneous but functionally interconnected endocytic vacuoles and vesicles with early endosomes and macropinosomes as commonly used gateways (Fig. 1). Viruses use the endocytic network of organelles for transit deeper into the cell and for penetration into the cytosol. Unlike some bacteria, they do not modify the composition and functions of the organelles. In early endosomes, the viruses are generally localized in the vacuolar part, sharing this volume with intralumenal vesicles (ILVs). If the particles have not penetrated already in early endosomes, they typically follow the pathway in the direction of late endosomes and endolysosomes (Huotari and Helenius 2011). This pathway involves a complex maturation program that prepares the endosome for fusion with lysosomes (see Klumperman and Raposa 2014; Wandinger-Ness and Zerial 2014). Macropinosomes can also deliver their cargo to lysosomes by fusing with late endosomes, endolysosomes, or lysosomes. Before this can occur, they also undergo a maturation process similar to endosomes. Defects in endosome and macropinosome maturation inhibit the productive entry of many viruses (Khor 
et al. 2003; Yamauchi et al. 2011; Fuchs and Blaas 2012; Huotari et al. 2012; Krzyzaniak et al. 2013).

The majority of viruses are acid-activated, that is, viral membrane fusion proteins and penetration mechanisms depend on exposure of the virus to low pH (Helenius et al. 1980). For viruses that penetrate from early endosomes, the $\mathrm{pH}$ threshold is 6 or above, and for late-penetrating viruses it is lower (Lozach et al. 2011a; Vazquez-Calvo et al. 2012a). Receptor interactions and proteolytic processing can also trigger escape with or without acid dependence (Chandran et al. 2005; Simmons et al. 2005; Krzyzaniak et al. 2013). These cues serve as a form of "wake up call" that tell the viruses that they are inside a cell and that it is time for penetration.

Much is known about the structure and function of fusion factors that cover the surface of envelope of viruses (Earp et al. 2005). They are oligomeric, type 1 membrane glycoproteins with large ectodomains. The prefusion conformation is metastable, which means that when triggered by low $\mathrm{pH}$ or other cues the proteins can undergo major conformational changes and alterations in oligomeric structure. This occurs without the input of additional energy. The changes involve the exposure of hydrophobic or amphipathic peptide sequences (fusion peptides) that allow the protein to insert into the target membrane. After generating a bridge between the two membranes, further conformational changes in clusters of these proteins allows the distance between the membrane to be reduced so that the hydration shell covering the lipid bilayer is disturbed in a focal site. This results in hemifusion (the innermost leaflets of the two bilayers fuse) followed by full fusion, when the outer leaflets also fuse.

\section{BACTERIA IN THE ENDOSOMAL NETWORK}

Of intracellular bacterial species, a minority, which includes Listeria, Shigella, Rickettsia, Francisella (Celli and Zahrt 2013), and also Salmonella (Knodler et al. 2010), Mycobacterium marinum (Smith et al. 2008), and Mycobacterium tuberculosis (van der Wel et al. 2007) have evolved like viruses to escape into the cytosol, where they replicate (Table 2). In the case of M. tuberculosis, the intracytosolic localization remains controversial. Intracytosolic bacteria use several molecular tools to escape from the primary internalization vacuoles. The best characterized is the Listeria pore-forming toxin listeriolysin O (Hamon et al. 2012). However, listeriolysin $\mathrm{O}$ is not always necessary for escape because listeriolysin $\mathrm{O}$ mutants can escape into the cytosol of some human cells, showing that escape can also be controlled by other unknown bacterial and cellular components. In the cytosol, the bacteria subvert cellular defense mechanisms such as antimicrobial peptides, or autophagy. Note that recent data indicate that the induction of autophagy does not necessarily lead to bacterial killing. There are even some bacteria that exploit the autophagic machinery for their own profit (for a recent review, see Mostowy and Cossart 2012).

The majority of intracellular bacteria remain in the lumen of endocytic vacuoles, which they modify to provide maximal protection and support (for review, see Kumar and Valdivia 2009). In epithelial cells, these intravacuolar bacteria include Salmonella, Chlamydia, Brucella, Bartonella, and Coxiella. In addition, a few bacteria such as Salmonella, Mycobacteria, Coxiella, and Legionella as well as some noninvasive bacteria are known to survive the killing by macrophages after phagocytosis, and can therefore be found alive inside vacuoles in these phagocytic cells (Fig. 2).

The properties of the bacteria-containing vacuoles differ greatly between bacteria. In some cases, the vacuoles acquire or retain properties and markers of early and late endosomal organelles. In others, they have ER-like characteristics and acquire unique properties not shared by organelles of the normal endocytosis pathway. Each bacterial species has evolved sophisticated cell biological mechanisms to ensure that remodeling of the vacuolar environment allows them to survive and replicate. Many of the bacteria devise strategies to ensure that the vacuoles do not mature to a point at which they would fuse with lysosomes. Because each pathogen appears to create a unique niche, we will 
highlight some of the known characteristics of each vacuole type.

\section{The Salmonella-Containing Vacuole (SCV)}

Salmonella replicates in vacuoles with properties of early and late endosomes. The specific characteristics of SCVs are influenced by the SPI-1 T3SS that controls bacterial invasion and the subsequent effects of the SPI-2 T3SS, which is activated $2-3 \mathrm{~h}$ after invasion ( $\mathrm{Yu}$ et al. 2010; Moest and Meresse 2013). The SPI-2 T3SS is responsible for the translocation of approximately 30 effector proteins across the vacuolar membrane, following acidification and nutritional deprivation of the vacuole lumen. The effectors are used for maintenance of the vacuolar membrane and localization of the vacuoles within the host cell, as well as interference with immune signaling and lysosome function.

Among the effectors translocated during invasion, SopB is a phosphoinositide phosphatase thought to arrest vacuole maturation by producing a high level of PI3P (thereby maintaining Rab5 localization in the vacuole) (Hernandez et al. 2004) and controlling the membrane surface charge of the SCVs (Bakowski et al. 2010). Subsequently, several other SPI-2 T3SS effector proteins participate in vacuole maintenance through interactions with host factors. For example, SifA interacts with the host scaffold protein SKIP, which interacts with the motor protein kinesin, an interaction required for SCV maturation (Diacovich et al. 2009). Effectors SseG and SseF localize the vacuole close to the Golgi apparatus where the SCV interacts with post-Golgi vesicular traffic (Mota et al. 2009). This may provide the bacteria with nutrients and membrane. SifA also interferes with Rab9-dependent retrograde trafficking of mannose-6-phosphate receptors that deliver lysosomal enzymes from the trans-Golgi network to lysosomes (McGourty et al. 2012). This causes rerouting of the enzymes out of the cell and a concomitant loss of lysosome functionality. This explains why SCVs are devoid of hydrolytic lysosomal enzymes but retain lysosomal membrane glycoproteins in the vacuolar membrane and interact dynamically with the endolysosomal system.

The Chlamydia-Containing Vacuole (the Inclusion)

Soon after endocytosis of Chlamydia, the vacuoles are transported along microtubules to the microtubule-organizing center (MTOC) close to the Golgi complex. They avoid fusion with endosomes and lysosomes. The inclusions interact with several host cell proteins involved in membrane trafficking, fusion, and organelle identity (Bastidas et al. 2013). Several Rabs are recruited including Rab6, 11, and 14. Rab6 and 11 facilitate sphingomyelin transport to the inclusions by regulating fragmentation of the Golgi complex into ministacks (Heuer et al. 2009; Rejman Lipinski et al. 2009). Phosphoinositides are key determinants of membrane identity and vesicle fusion. Several proteins associated with PI4P metabolism (such as OCRL, PI4KIIa, and Arf1) are recruited to the inclusions. In addition to recruiting Rab GTPases, Chlamydia may regulate fusion with host vesicles by recruiting host SNAREs that serve as key factors of the intracellular fusion machinery; among them are two Golgi-specific SNAREs (Syntaxin 6 and GS215) and three endocytic SNAREs (Vamp3, 7, and 8) (Grieshaber et al. 2002).

By establishing a close association with the Golgi complex, Chlamydia inclusions intercept sphingomyelin- and cholesterol-containing exocytic vesicles (Hackstadt et al. 1996). They also interact with multivesicular bodies that can act as a source of sphingolipids and cholesterol, with lipid droplets that may serve as a source of neutral lipids, and with mitochondria and lysosomes that may be a source of essential amino acids derived from host protein degradation. Strikingly, elements of the cytoskeleton play an important role in vacuole stabilization (Kumar and Valdivia 2008).

\section{The Legionella-Containing Vacuole (LCV)}

Using a type IV secretion system, Legionella prevents fusion of the vacuole in which it resides 
with endosomal compartments and also blocks autophagy. The vacuole recruits vesicles derived from the ER to create a specialized compartment in which it replicates (Roy and Tilney 2002; Isberg et al. 2009; Hubber and Roy 2010). Fusion is driven by the interaction between a plasma membrane complex consisting of syntaxin and SNAP23 and the ER-localized vSNARE protein Sec22b. In addition to using host SNAREs, Legionella pneumophila encodes SNARE mimics that directly modulate membrane transport (Delevoye et al. 2008; Paumet et al. 2009). Host GTPases that regulate membrane transport are direct targets of Legionella effectors. In particular, Rab1 is recruited to the vacuole, and its activity is controlled by a network of bacterial effectors including DrrA, a GEF protein, and LidA, which interacts with Rab1 on the vacuolar membrane to tether ERderived vesicles that remodel the LCV (Machner and Isberg 2006; Murata et al. 2006).

\section{The Brucella-Containing Vacuole (BCV)}

The Brucella abortus replicative vacuole is derived from the endocytic vacuole and matures into an ER-derived organelle (Starr et al. 2008). Brucella-containing vacuoles (BCVs) rapidly acquire several late endosome markers including Rab7 and its effector Rab-interacting lysosomal protein (RILP) (Celli 2006). They are accessible to fluid-phase markers either delivered to the cells or preloaded into lysosomes, indicating that they interact with late endosomes and lysosomes. Intermediate BCVs are acidic and display proteolytic activity up to 12 $\mathrm{h}$ postinfection (Celli 2006). Expression of dominant-negative Rab7 prevents conversion of the vacuoles into ER-derived organelles and inhibits replication of Brucella, indicating that $\mathrm{BCV}$ maturation requires interactions with functional late endosomal factors (Celli 2006). In the first hours postinfection, Brucella vacuoles merge with late endosomes, with the acquisition of the Lamp1 marker, and the vacuolar $\mathrm{pH}$ drops to 4 , which is required to activate the VirB type IV secretion machinery. This, in turn, allows the secretion of effectors that prevent the fusion of $\mathrm{BCV}$ with lysosomes (Cel- li et al. 2003). VirB mutants merge with lysosomes where bacteria are killed (Lapaque et al. 2005). Recently, a Brucella protein RicA was shown to recruit Rab2, showing that several Rabs are contributing to the maturation of BCVs (de Barsy et al. 2011; von Bargen et al. 2012).

\section{The Coxiella Vacuole}

C. burnetii is the only bacterial pathogen that has evolved to survive and replicate in a lysosome-derived vacuole containing active proteolytic enzymes (Voth and Heinzen 2007). Upon uptake, Coxiella is found in a tight-fitting vacuole positive for early endosomal and autophagy markers (Rab5 and LC3, respectively) (Gutierrez et al. 2005; Romano et al. 2007). The Coxiella-containing vacuoles then merge with late endosomes recruiting markers such as Rab7 (Romano et al. 2007) and acidify, thereby activating the bacterial T4SS (Newton et al. 2013). Coxiella then secretes effectors that drive the generation of a lysosome-derived fusogenic parasitophorous vacuole that occupies the vast majority of the cell cytosol (Comerci et al. 2001; Voth and Heinzen 2007). Upon depletion of intravacuolar nutrients, bacteria enter a latency phase and persist within infected cells, which are protected from apoptosis by a bacterialdriven mechanism (Voth and Heinzen 2007; Beare et al. 2011).

\section{The Mycobacterium tuberculosis Vacuole}

M. tuberculosis is internalized in macrophages and is able to arrest the normal maturation of its phagosome. It resides in a vacuole that retains many of the characteristics of a sorting endosome. It has a $\mathrm{pH}$ of 6.4 because it lacks the $\mathrm{V}$ ATPase (Sturgill-Koszycki et al. 1994). However, upon activation of the macrophage, the blocking is overcome and the bacterium is exposed to a lower $\mathrm{pH}$. The bacterium is able to adapt its transcriptional program to this drop in $\mathrm{pH}$ (Soldati and Neyrolles 2012; Russell 2013). As said above, an intracytosolic localization of $M$. tuberculosis remains controversial. 


\section{CONCLUDING REMARKS AND FUTURE DIRECTIONS}

The reasons why viruses and invasive bacteria make use of endocytosis to enter host cells are fundamentally different. Bacteria seek out intracellular compartments in which they can grow and replicate under optimal conditions. Many remain vacuolar, and some enter the cytosol. Viruses enter cells (the cytosol and the nucleus) because they have no other way to multiply. They need access to the biosynthetic machinery and other services offered by cells. Successful entry of a virus results in the ultimate destruction of the particle, whereas bacteria stay intact and continue to live and divide.

The remodeling and reprogramming of endocytic vacuoles are of central importance for many of the invasive bacteria. For viruses, the vacuoles of the endosomal network are merely transient stations on the way to the cytosol. Rather than modifying them, viruses generally count on the normal maturation and function of these organelles for successful entry.

Many of the invasive bacteria inject effector proteins into the cytosol of host cells to initiate endocytosis and other changes. Others use receptors that when interacting with their normal ligands are endocytosed via the CME. Viruses are also capable of triggering their endocytosis and other changes in cells, but they do this indirectly using existing cell-surface receptors and existing signaling pathways.

Because viruses depend on the cellular machinery for synthesis, they acquire a certain molecular "imprinting" by the host cells that bacteria do not. The lipids are, for example, taken from host cell membranes, and carbohydrate moieties reflect the properties of host glycans. Some viruses carry host cell proteins, ribosomes, nucleosomes, histones, and actin filaments as structural components. Although this imprinting can add functionality and provide camouflage, it can also be used against them by animal hosts, for example, through the detection of the "foreign" origin of incoming arthropod-borne viruses.

A long history of coevolution and cohabitation has allowed invasive bacteria and viruses to optimize every aspect of their interaction with host cells. As we have seen, they have become masters at manipulating endocytosis for their own ends. Endocytosis is not only used for entry and replication but also for intoxication by toxins, protection against immune defenses, and cell-mediated movement and transmission between tissues within host organisms.

At a first glance, it may seem that each intracellular pathogen has evolved unique solutions. However, given that virtually all depend on the endocytic machinery of the host cell, the options are probably limited. It will be important to expand our cell biological understanding of endocytic pathways and to view already-existing information in this field from the angle of pathogens. The search for cellular targets and new drugs that prevent endocytic uptake and other steps in pathogen entry needs to be better informed by state-of-the-art cell biological input. A better understanding of the endocytic pathways in host cells is likely to provide new options in the development of new antiviral and antibacterial strategies. Development of new therapies against infectious diseases is of utmost importance in a world vulnerable to epidemics and pandemics caused by established and emerging pathogens.

Pathogens can also be valuable tools in basic and applied biology. They have been used to study membrane biology, signal transduction, actin-based motility, and so on. Viruses, viruslike particles, pseudotype particles, and mutants, for example, are often used as model ligands in endocytosis research. Latex beads coated with bacterial proteins can also be used. The advantages include the possibility to develop sensitive quantitative assays with the infection itself, providing an easily detected end point. Moreover, it is possible to follow the fate of single pathogens in live cells using light microscopy at increasingly high resolution. Viruses and bacteria are also used as delivery vehicles and carriers for otherwise impermeable substances and macromolecules such as drugs, genes, and proteins.

\section{ACKNOWLEDGMENTS}

We thank Miriam Stöber, Jason Mercer, Matteo Bonazzi, David Holden, Wolf-Dietrich Hardt, 
Craig Roy, and David Ribet for critical reading of the manuscript. We also greatly acknowledge Andreas Kubacher and Yohei Yamauchi for help in figure preparation. A.H. is supported by grants from the Swiss National Science Foundation and the ERC. P.C. is supported by the Pasteur Institute, Inserm, and the INRA and an ERC Advanced Grant. P.C. is a senior investigator of the Howard Hughes Medical Institute.

\section{REFERENCES}

${ }^{*}$ Reference is also in this collection.

Agbor TA, McCormick BA. 2011. Salmonella effectors: Important players modulating host cell function during infection. Cell Microbiol 13: 1858-1869.

Anderson HA, Chen Y, Norkin LC. 1996. Bound simian virus 40 translocates to caveolin-enriched membrane domains, and its entry is inhibited by drugs that selectively disrupt caveolae. Mol Biol Cell 7: 1825-1834.

Backert S, Meyer TF. 2006. Type IV secretion systems and their effectors in bacterial pathogenesis. Curr Opin Microbiol 9: 207-217.

Bakowski MA, Braun V, Lam GY, Yeung T, Heo WD, Meyer T, Finlay BB, Grinstein S, Brumell JH. 2010. The phosphoinositide phosphatase SopB manipulates membrane surface charge and trafficking of the Salomnella-containg vacuole. Cell Host Microbe 7: 453-462.

Bastidas RJ, Elwell CA, Engel JN, Valdivia RH. 2013. Chlamydial intracellular survival strategies. Cold Spring Harb Perspect Med 3: a010256.

Beare PA, Gilk SD, Larson CL, Hill J, Stead CM, Omsland A, Cockrell DC, Howe D, Voth DE, Heinzen RA. 2011. Dot/Icm type IVB secretion system requirements for Coxiella burnetii growth in human macrophages. MBio 2: e00175-11.

Berinstein A, Roivainen M, Hovi T, Mason PW, Baxt B. 1995. Antibodies to the vitronectin receptor (integrin $\alpha v \beta 3$ ) inhibit binding and infection of foot-and-mouth disease virus to cultured cells. J Virol 69: 2664-2666.

Berryman S, Clark S, Monaghan P, Jackson T. 2005. Early events in integrin $\alpha v \beta 6$-mediated cell entry of foot-andmouth disease virus. J Virol 79: 8519-8534.

Berryman S, Brooks E, Burman A, Hawes P, Roberts R, Netherton C, Monaghan P, Whelband M, Cottam E, Elazar Z, et al. 2012. Foot-and-mouth disease virus induces autophagosomes during cell entry via a class III phosphatidylinositol 3-kinase-independent pathway. J Virol 86: $12940-12953$.

Bierne H, Cossart P. 2002. InlB, a surface protein of Listeria monocytogenes that behaves as an invasin and a growth factor. J Cell Sci 115: 3357-3367.

Bierne H, Gouin E, Roux P, Caroni P, Yin HL, Cossart P. 2001. A role for cofilin and LIM kinase in Listeria-induced phagocytosis. J Cell Biol 155: 101-112.

Boleti H, Benmerah A, Ojcius DM, Cerf-Bensussan N, Dautry-Varsat A. 1999. Chlamydia infection of epithelial cells expressing dynamin and Eps15 mutants: Clathrin-independent entry into cells and dynamin-dependent productive growth. J Cell Sci 112: 1487-1496.

Bonazzi M, Veiga E, Pizarro-Cerda J, Cossart P. 2008. Successive post-translational modifications of E-cadherin are required for InlA-mediated internalization of Listeria monocytogenes. Cell Microbiol 10: 2208-2222.

Bonazzi M, Vasudevan L, Mallet A, Sachse M, Sartori A, Prevost MC, Roberts A, Taner SB, Wilbur JD, Brodsky FM, et al. 2011. Clathrin phosphorylation is required for actin recruitment at sites of bacterial adhesion and internalization. J Cell Biol 195: 525-536.

Brandenburg B, Lee LY, Lakadamyali M, Rust MJ, Zhuang X, Hogle JM. 2007. Imaging poliovirus entry in live cells. PLoS Biol 5: e183.

* Brodsky FM, Sosa RT, Ybe JA, O’Hallaran TJ. 2014. Unconventional functions for clathrin, ESCRTs, and other endocytic regulators in the cytoskeleton, cell cycle, nucleus, and beyond: Links to human disease. Cold Spring Harb Perspect Biol doi: 10.1101/cshperspect.a017004.

Bulgin R, Raymond B, Garnett JA, Frankel G, Crepin VF, Berger CN, Arbeloa A. 2010. Bacterial guanine nucleotide exchange factors SopE-like and WxxxE effectors. Infect Immun 78: 1417-1425.

Burckhardt CJ, Suomalainen M, Schoenenberger P, Boucke K, Hemmi S, Greber UF. 2011. Drifting motions of the adenovirus receptor CAR and immobile integrins initiate virus uncoating and membrane lytic protein exposure. Cell Host Microbe 10: 105-117.

Cain RJ, Hayward RD, Koronakis V. 2008. Deciphering interplay between Salmonella invasion effectors. PLoS pathogens 4: e1000037.

Campadelli-Fiume G, Menotti L, Avitabile E, Gianni T. 2012. Viral and cellular contributions to herpes simplex virus entry into the cell. Curr Opin Virol 2: 28-36.

Carayol N, Tran Van Nhieu G. 2013. Tips and tricks about Shigella invasion of epithelial cells. Curr Opin Microbiol 16: $32-37$.

Celli J. 2006. Surviving inside a macrophage: The many ways of Brucella. Res Microbiol 157: 93-98.

Celli J, Zahrt TC. 2013. Mechanisms of Francisella tularensis intracellular pathogenesis. Cold Spring Harb Perspect Med 3: $\mathrm{a} 010314$.

Celli J, de Chastellier C, Franchini DM, Pizarro-Cerda J, Moreno E, Gorvel JP. 2003. Brucella evades macrophage killing via VirB-dependent sustained interactions with the endoplasmic reticulum. J Exp Med 198: 545-556.

Chamot-Rooke J, Mikaty G, Malosse C, Soyer M, Dumont A, Gault J, Imhaus AF, Martin P, Trellet M, Clary G, et al. 2011. Posttranslational modification of pili upon cell contact triggers $N$. meningitidis dissemination. Science 331: 778-782.

Chandran K, Sullivan NJ, Felbor U, Whelan SP, Cunningham JM. 2005. Endosomal proteolysis of the Ebola virus glycoprotein is necessary for infection. Science 308: $1643-1645$.

Comerci DJ, Martinez-Lorenzo MJ, Sieira R, Gorvel JP, Ugalde RA. 2001. Essential role of the VirB machinery in the maturation of the Brucella abortus-containing vacuole. Cell Microbiol 3: 159-168. 
Cossart P. 2011. Illuminating the landscape of host-pathogen interactions with the bacterium Listeria monocytogenes. Proc Natl Acad Sci 108: 19484-19491.

Cossart P, Roy CR. 2010. Manipulation of host membrane machinery by bacterial pathogens. Curr Opin Cell Biol 22: 547-554.

Cossart P, Sansonetti PJ. 2004. Bacterial invasion: The paradigms of enteroinvasive pathogens. Science 304: $242-$ 248.

Coyne CB, Bergelson JM. 2006. Virus-induced Abl and Fyn kinase signals permit coxsackievirus entry through epithelial tight junctions. Cell 124: 119-131.

Craig L, Pique ME, Tainer JA. 2004. Type IV pilus structure and bacterial pathogenicity. Nat Rev Microbiol 2: 363378.

Cureton DK, Massol RH, Saffarian S, Kirchhausen TL, Whelan SP. 2009. Vesicular stomatitis virus enters cells through vesicles incompletely coated with clathrin that depend upon actin for internalization. PLoS Pathog 5: e1000394.

Dales S. 1978. Penetration of animal viruses into cells. In Transport of macromolecules in cellular systems (ed. Silverstein SC), pp. 47-67. Dahlem Konferzen, Berlin.

Damm EM, Pelkmans L, Kartenbeck J, Mezzacasa A, Kurzchalia T, Helenius A. 2005. Clathrin- and caveolin-1-independent endocytosis: entry of simian virus 40 into cells devoid of caveolae. J Cell Biol 168: 477-488.

Danthi P, Guglielmi KM, Kirchner E, Mainou B, Stehle T, Dermody TS. 2010. From touchdown to transcription: The reovirus cell entry pathway. Curr Top Microbiol Immunol 343: 91-119.

Day PM, Thompson CD, Schowalter RM, Lowy DR, Schiller JT. 2013. Identification of a role for the trans-Golgi network in human papillomavirus 16 pseudovirus infection. J Virol 87: 3862-3870.

de Barsy M, Jamet A, Filopon D, Nicolas C, Laloux G, Rual JF, Muller A, Twizere JC, Nkengfac B, Vandenhaute J, et al. 2011. Identification of a Brucella spp. secreted effector specifically interacting with human small GTPase Rab2. Cell Microbiol 13: 1044-1058.

Dehio C. 2004. Molecular and cellular basis of bartonella pathogenesis. Annu Rev Microbiol 58: 365-390.

Dehio C, Meyer M, Berger J, Schwarz H, Lanz C. 1997. Interaction of Bartonella henselae with endothelial cells results in bacterial aggregation on the cell surface and the subsequent engulfment and internalisation of the bacterial aggregate by a unique structure, the invasome. J Cell Sci 110: 2141-2154.

Delevoye C, Nilges M, Dehoux P, Paumet F, Perrinet S, Dautry-Varsat A, Subtil A. 2008. SNARE protein mimicry by an intracellular bacterium. PLoS Pathog 4: e1000022.

DeTulleo L, Kirchhausen T. 1998. The clathrin endocytic pathway in viral infection. Embo J 17: 4585-4593.

de Vries E, Tscherne DM, Wienholts MJ, Cobos-Jimenez V, Scholte F, Garcia-Sastre A, Rottier PJ, de Haan CA. 2011. Dissection of the influenza A virus endocytic routes reveals macropinocytosis as an alternative entry pathway. PLoS Pathog 7: e1001329.

Diacovich L, Dumont A, Lafitte D, Soprano E, Guilhon AA, Bignon C, Gorvel JP, Bourne Y, Meresse S. 2009. Interaction between the SifA virulence factor and its host target
SKIP is essential for Salmonella pathogenesis. J Biol Chem 284: 33151-33160.

Di Simone C, Zandotti MA, Buchmeier MJ. 1994. Acidic pH triggers LCMV membrane fusion activity and conformational change in the glycoprotein spike. Virology 198: 455-465.

Donaldson JG, Porat-Shliom N, Cohen LA. 2009. Clathrinindependent endocytosis: A unique platform for cell signaling and PM remodeling. Cell Signal 21: 1-6.

Doxsey SJ, Brodsky FM, Blank GS, Helenius A. 1987. Inhibition of endocytosis by anti-clathrin antibodies. Cell 50: 453-463.

Dramsi S, Caliot E, Bonne I, Guadagnini S, Prevost MC, Kojadinovic M, Lalioui L, Poyart C, Trieu-Cuot P. 2006. Assembly and role of pili in group B streptococci. Mol Microbiol 60: 1401-1413.

Earp LJ, Delos SE, Park HE, White JM. 2005. The many mechanisms of viral membrane fusion proteins. Curr Top Microbiol Immunol 285: 25-66.

Ehrlich M, Boll W, Van Oijen A, Hariharan R, Chandran K, Nibert ML, Kirchhausen T. 2004. Endocytosis by random initiation and stabilization of clathrin-coated pits. Cell 118: 591-605.

Eicher SC, Dehio C. 2012. Bartonella entry mechanisms into mammalian host cells. Cell Microbiol 14: 1166-1173.

Eierhoff T, Hrincius ER, Rescher U, Ludwig S, Ehrhardt C. 2010. The epidermal growth factor receptor (EGFR) promotes uptake of influenza A viruses (IAV) into host cells. PLoS Pathog 6: e1001099.

Eisenberg RJ, Atanasiu D, Cairns TM, Gallagher JR, Krummenacher C, Cohen GH. 2012. Herpes virus fusion and entry: A story with many characters. Viruses 4: 800-832.

Engel S, Heger T, Mancini R, Herzog F, Kartenbeck J, Hayer A, Helenius A. 2011. Role of endosomes in simian virus 40 entry and infection. J Virol 85: 4198-4211.

English TJ, Hammer DA. 2005. The effect of cellular receptor diffusion on receptor-mediated viral binding using Brownian adhesive dynamics (BRAD) simulations. Biophys J 88: 1666-1675.

Eto DS, Gordon HB, Dhakal BK, Jones TA, Mulvey MA. 2008. Clathrin, AP2, and the NPXY-binding subset of alternate endocytic adaptors facilitate FimH-mediated bacterial invasion of host cells. Cell Microbiol 10: 25532567.

Ewers H, Romer W, Smith AE, Bacia K, Dmitrieff S, Chai W, Mancini R, Kartenbeck J, Chambon V, Berland L, et al. 2010. GM1 structure determines SV40-induced membrane invagination and infection. Nat Cell Biol 12: 1118.

Falker S, Nelson AL, Morfeldt E, Jonas K, Hultenby K, Ries J, Melefors O, Normark S, Henriques-Normark B. 2008. Sortase-mediated assembly and surface topology of adhesive pneumococcal pili. Mol Microbiol 70: 595-607.

Figueira R, Holden DW. 2012. Functions of the Salmonella pathogenicity island 2 (SPI-2) type III secretion system effectors. Microbiology 158: 1147-1161.

Finkelshtein D, Werman A, Novick D, Barak S, Rubinstein M. 2013. LDL receptor and its family members serve as the cellular receptors for vesicular stomatitis virus. Proc Natl Acad Sci 110: 7306-7311. 
Flipse J, Wilschut J, Smit JM. 2013. Molecular mechanisms involved in antibody-dependent enhancement of dengue virus infection in humans. Traffic 14: 25-35.

Fuchs R, Blaas D. 2012. Productive entry pathways of human rhinoviruses. Adv Virol 2012: 826301.

Fukumatsu M, Ogawa M, Arakawa S, Suzuki M, Nakayama K, Shimizu S, Kim M, Mimuro H, Sasakawa C. 2012. Shigella targets epithelial tricellular junctions and uses a noncanonical clathrin-dependent endocytic pathway to spread between cells. Cell Host Microbe 11: 325-336.

Gabel BR, Elwell C, van Ijzendoorn SC, Engel JN. 2004. Lipid raft-mediated entry is not required for Chlamydia trachomatis infection of cultured epithelial cells. Infect Immun 72: 7367-7373.

Gaillard JL, Berche P, Frehel C, Gouin E, Cossart P. 1991. Entry of L. monocytogenes into cells is mediated by internalin, a repeat protein reminiscent of surface antigens from Gram-positive cocci. Cell 65: 1127-1141.

Galan JE, Wolf-Watz H. 2006. Protein delivery into eukaryotic cells by type III secretion machines. Nature 444: 567-573.

Ghigo E, Kartenbeck J, Lien P, Pelkmans L, Capo C, Mege JL, Raoult D. 2008. Ameobal pathogen mimivirus infects macrophages through phagocytosis. PLoS Pathog 4: e1000087.

Gilbert JM, Benjamin TL. 2000. Early steps of polyomavirus entry into cells. J Virol 74: 8582-8588.

Gouin E, Welch MD, Cossart P. 2005. Actin-based motility of intracellular pathogens. Curr Opin Microbiol 8: 35-45.

Grieshaber S, Swanson JA, Hackstadt T. 2002. Determination of the physical environment within the Chlamydia trachomatis inclusion using ion-selective ratiometric probes. Cell Microbiol 4: 273-283.

Grove J, Marsh M. 2011. The cell biology of receptor-mediated virus entry. J Cell Biol 195: 1071-1082.

Gutierrez MG, Vazquez CL, Munafo DB, Zoppino FC, Beron W, Rabinovitch M, Colombo MI. 2005. Autophagy induction favours the generation and maturation of the Coxiella-replicative vacuoles. Cell Microbiol 7: 981-993.

Hackstadt T, Rockey DD, Heinzen RA, Scidmore MA. 1996. Chlamydia trachomatis interrupts an exocytic pathway to acquire endogenously synthesized sphingomyelin in transit from the Golgi apparatus to the plasma membrane. EMBO J 15: 964-977.

Hamon MA, Ribet D, Stavru F, Cossart P. 2012. Listeriolysin O: The Swiss army knife of Listeria. Trends Microbiol 20: $360-368$.

Hanisch J, Kolm R, Wozniczka M, Bumann D, Rottner K, Stradal TE. 2011. Activation of a RhoA/myosin II-dependent but Arp2/3 complex-independent pathway facilitates Salmonella invasion. Cell Host Microbe 9: 273-285.

Helenius A. 2007. Virus entry and uncoating. In Fields virology (ed. Knipe DM), pp. 99-118. Lippincott Williams \& Wilkins, Philadelphia.

Helenius A, Kartenbeck J, Simons K, Fries E. 1980. On the entry of Semliki Forest virus into BHK-21 cells. J Cell Biol 84: $404-420$.

Henry RM, Hoppe AD, Joshi N, Swanson JA. 2004. The uniformity of phagosome maturation in macrophages. J Cell Biol 164: 185-194.
Hernandez LD, Hueffer K, Wenk MR, Galán JE. 2004. Salmonella modulates vesicular traffic by altering phosphoinositide metabolism. Science 304: 1805-1807.

Heuer D, Rejman Lipinski A, Machuy N, Karlas A, Wehrens A, Siedler F, Brinkmann V, Meyer TF. 2009. Chlamydia causes fragmentation of the Golgi compartment to ensure reproduction. Nature 457: 731-735.

Hoffmann PR, deCathelineau AM, Ogden CA, Leverrier Y, Bratton DL, Daleke DL, Ridley AJ, Fadok VA, Henson PM. 2001. Phosphatidylserine (PS) induces PS receptor-mediated macropinocytosis and promotes clearance of apoptotic cells. J Cell Biol 155: 649-659.

Hubber A, Roy CR. 2010. Modulation of host cell function by Legionella pneumophila type IV effectors. Annu Rev Cell Dev Biol 26: 261-283.

Humphreys D, Davidson A, Hume PJ, Koronakis V. 2012. Salmonella virulence effector SopE and Host GEF ARNO cooperate to recruit and activate WAVE to trigger bacterial invasion. Cell Host Microbe 11: 129-139.

Hunt CL, Lennemann NJ, Maury W. 2012. Filovirus entry: A novelty in the viral fusion world. Viruses 4: 258-275.

Huotari J, Helenius A. 2011. Endosome maturation. EMBO J 30: 3481-3500.

Huotari J, Meyer-Schaller N, Katheder P, Hubner M, Stauffer S, Mancini R, Helenius A, Peter M. 2012. Cullin-3 regulates late endosome maturation. ProcNatl Acad Sci 109: 823-828.

Ireton K, Payrastre B, Chap H, Ogawa W, Sakaue H, Kasuga M, Cossart P. 1996. A role for phosphoinositide 3-kinase in bacterial invasion. Science 274: 780-782.

Ireton K, Payrastre B, Cossart P. 1999. The Listeria monocytogenes protein InlB is an agonist of mammalian phosphoinositide 3-kinase. J Biol Chem 274: 17025-17032.

Isberg RR, Barnes P. 2001. Subversion of integrins by enteropathogenic Yersinia. J Cell Sci 114: 21-28.

Isberg RR, Voorhis DL, Falkow S. 1987. Identification of invasin: A protein that allows enteric bacteria to penetrate cultured mammalian cells. Cell 50: 769-778.

Isberg RR, O'Connor TJ, Heidtman M. 2009. The Legionella pneumophila replication vacuole: Making a cosy niche inside host cells. Nat Rev Microbiol 7: 13-24.

Jewett TJ, Miller NJ, Dooley CA, Hackstadt T. 2010. The conserved Tarp actin binding domain is important for chlamydial invasion. PLoS Pathog 6: e1000997.

Johannsdottir HK, Mancini R, Kartenbeck J, Amato L, Helenius A. 2009. Host cell factors and functions involved in vesicular stomatitis virus entry. J Virol 83: 440-453.

Johns HL, Berryman S, Monaghan P, Belsham GJ, Jackson T. 2009. A dominant-negative mutant of rab5 inhibits infection of cells by foot-and-mouth disease virus: Implications for virus entry. J Virol 83: 6247-6256.

Kamhi E, Joo EJ, Dordick JS, Linhardt RJ. 2013. Glycosaminoglycans in infectious disease. Biol Rev Camb Philos Soc 88: $928-943$.

Kenny B, DeVinney R, Stein M, Reinscheid DJ, Frey EA, Finlay BB. 1997. Enteropathogenic E. coli (EPEC) transfers its receptor for intimate adherence into mammalian cells. Cell 91: 511-520.

Khan AG, Pickl-Herk A, Gajdzik L, Marlovits TC, Fuchs R, Blaas D. 2010. Human rhinovirus 14 enters rhabdomyosarcoma cells expressing Icam-1 by a clathrin-, caveolin-, 
and flotillin-independent pathway. J Virol 84: 39843992.

Khor R, McElroy LJ, Whittaker GR. 2003. The ubiquitinvacuolar protein sorting system is selectively required during entry of influenza virus into host cells. Traffic 4: 857-868.

Kirkham M, Parton RG. 2005. Clathrin-independent endocytosis: New insights into caveolae and non-caveolar lipid raft carriers. Biochim Biophys Acta 1746: 349-363.

* Klumperman J, Raposo G. 2014. The complex ultrastructure of the endolysosomal system. Cold Spring Harb Perspect Biol doi: 10.1101/cshperspect.a016857.

Knodler LA, Vallance BA, Celli J, Winfree S, Hansen B, Montero M, Steele-Mortimer O. 2010. Dissemination of invasive Salmonella via bacterial-induced extrusion of mucosal epithelia. Proc Natl Acad Sci 107: 1773317738 .

Kreikemeyer B, Klenk M, Podbielski A. 2004. The intracellular status of Streptococcus pyogenes: Role of extracellular matrix-binding proteins and their regulation. Int J Med Microbiol 294: 177-188.

Krzyzaniak M, Zumstein MT, Gerez JA, Picotti PAH. 2013. Host cell entry of Respiratory Syncytial Virus involves macropinocytosis followed by proteolytic activation of the F protein. PLoS Pathog 9: el003309.

Kubo Y, Hayashi H, Matsuyama T, Sato H, Yamamoto N. 2012. Retrovirus entry by endocytosis and cathepsin proteases. Adv Virol 2012: 640894.

Kuhbacher A, Dambournet D, Echard A, Cossart P, Pizarro-Cerda J. 2012. Phosphatidylinositol 5-phosphatase oculocerebrorenal syndrome of Lowe protein (OCRL) controls actin dynamics during early steps of Listeria monocytogenes infection. J Biol Chem 287: 13128-13136.

Kumar Y, Valdivia RH. 2008. Actin and intermediate filaments stabilize the Chlamydia trachomatis vacuole by forming dynamic structural scaffolds. Cell Host Microbe 4: $159-169$.

Kumar Y, Valdivia RH. 2009. Leading a sheltered life: Intracellular pathogens and maintenance of vacuolar compartments. Cell Host Microbe 5: 593-601.

Kunz S. 2009. Receptor binding and cell entry of Old World arenaviruses reveal novel aspects of virus-host interaction. Virology 387: 245-249.

Lakadamyali M, Rust MJ, Zhuang X. 2006. Ligands for clathrin-mediated endocytosis are differentially sorted into distinct populations of early endosomes. Cell 124: $997-$ 1009.

Lamaze C, Dujeancourt A, Baba T, Lo CG, Benmerah A, Dautry-Varsat A. 2001. Interleukin 2 receptors and detergent-resistant membrane domains define a clathrinindependent endocytic pathway. Mol Cell 7: 661-671.

Lane BJ, Mutchler C, Al Khodor S, Grieshaber SS, Carabeo RA. 2008. Chlamydial entry involves TARP binding of guanine nucleotide exchange factors. PLoS Pathog 4: e1000014.

Lapaque N, Moriyon I, Moreno E, Gorvel JP. 2005. Brucella lipopolysaccharide acts as a virulence factor. Curr Opin Microbiol 8: 60-66.

Lecuit M, Hurme R, Pizarro-Cerda J, Ohayon H, Geiger B, Cossart P. 2000. A role for $\alpha$ - and $\alpha$-catenins in bacterial uptake. Proc Natl Acad Sci 97: 10008-10013.
Lemke G, Burstyn-Cohen T. 2010. TAM receptors and the clearance of apoptotic cells. Ann NY Acad Sci 1209: 23-29.

Lim JP, Gleeson PA. 2011. Macropinocytosis: An endocytic pathway for internalising large gulps. Immunol Cell Biol 89: $836-843$.

Lipovsky A, Popa A, Pimienta G, Wyler M, Bhan A, Kuruvilla L, Guie MA, Poffenberger AC, Nelson CD, Atwood WJ, et al. 2013. Genome-wide siRNA screen identifies the retromer as a cellular entry factor for human papillomavirus. Proc Natl Acad Sci 110: 7452-7457.

Lonberg-Holm K, Philipson L. 1974. Early interaction between animal viruses and cells. Monogr Virol 9: 1-148.

Lopez S, Arias CF. 2006. Early steps in rotavirus cell entry. Curr Top Microbiol Immunol 309: 39-66.

Lozach PY, Huotari J, Helenius A. 2011a. Late-penetrating viruses. Curr Opin Virol 1: 35-43.

Lozach PY, Kuhbacher A, Meier R, Mancini R, Bitto D, Bouloy M, Helenius A. 2011b. DC-SIGN as a receptor for phleboviruses. Cell Host Microbe 10: 75-88.

Machner MP, Isberg RR. 2006. Targeting of host Rab GTPase function by the intravacuolar pathogen Legionella pneumophila. Dev Cell 11: 47-56.

Matlin KS, Reggio H, Helenius A, Simons K. 1981. Infectious entry pathway of influenza virus in a canine kidney cell line. J Cell Biol 91: 601-613.

Matlin KS, Reggio H, Helenius A, Simons K. 1982. Pathway of vesicular stomatitis virus entry leading to infection. $J$ Mol Biol 156: 609-631.

May RC, Machesky LM. 2001. Phagocytosis and the actin cytoskeleton. J Cell Sci 114: 1061-1077.

Mayor S, Pagano RE. 2007. Pathways of clathrin-independent endocytosis. Nat Rev Mol Cell Biol 8: 603-612.

* Mayor S, Parton RG, Donaldson JG. 2014. Clathrin-independent pathways of endocytosis. Cold Spring Harb Perspect Biol doi: 10.1101/cshperspect.a016758.

McGourty K, Thurston TL, Matthews SA, Pinaud L, Mota LJ, Holden DW. 2012. Salmonella inhibits retrograde trafficking of mannose-6-phosphate receptors and lysosome function. Science 338: 963-967.

Meertens L, Carnec X, Lecoin MP, Ramdasi R, Guivel-Benhassine F, Lew E, Lemke G, Schwartz O, Amara A. 2012. The TIM and TAM families of phosphatidylserine receptors mediate dengue virus entry. Cell Host Microbe 12: $544-557$.

Meier O, Boucke K, Hammer SV, Keller S, Stidwill RP, Hemmi S, Greber UF. 2002. Adenovirus triggers macropinocytosis and endosomal leakage together with its clathrin-mediated uptake. J Cell Biol 158: 1119-1131.

Mengaud J, Ohayon H, Gounon P, Mege RM, Cossart P. 1996. E-Cadherin is the receptor for internalin, a surface protein required for entry of L. monocytogenes into epithelial cells. Cell 84: 923-932.

Mercer J, Helenius A. 2008. Vaccinia virus uses macropinocytosis and apoptotic mimicry to enter host cells. Science 320: 531-535.

Mercer J, Helenius A. 2010. Apoptotic mimicry: Phosphatidylserine-mediated macropinocytosis of vaccinia virus. Ann NY Acad Sci 1209: 49-55. 
P. Cossart and A. Helenius

Mercer J, Helenius A. 2012. Gulping rather than sipping: Macropinocytosis as a way of virus entry. Curr Opin Microbiol 15: 490-499.

Mercer J, Knebel S, Schmidt FI, Crouse J, Burkard C, Helenius A. 2010a. Vaccinia virus strains use distinct forms of macropinocytosis for host-cell entry. Proc Natl Acad Sci 107: 9346-9351

Mercer J, Schelhaas M, Helenius A. 2010b. Virus entry by endocytosis. Annu Rev Biochem 79: 803-833.

Mijouin L, Rosselin M, Bottreau E, Pizarro-Cerda J, Cossart P, Velge P, Wiedemann A. 2012. Salmonella enteritidis Rck-mediated invasion requires activation of Racl, which is dependent on the class I PI3-kinases-Akt signaling pathway. FASEB J 26: 1569-1581.

Misselwitz B, Kreibich SK, Rout S, Stecher B, Periaswamy B, Hardt WD. 2011. Salmonella enterica serovar Typhimurium binds to HeLa cells via Fim-mediated reversible adhesion and irreversible type three secretion system 1-mediated docking. Infect Immun 79: 330-341.

Misselwitz B, Barrett N, Kreibich S, Vonaesch P, Andritschke D, Rout S, Weidner K, Sormaz M, Songhet P, Horvath P, et al. 2012. Near surface swimming of Salmonella Typhimurium explains target-site selection and cooperative invasion. PLoS Pathog 8: e1002810.

Moest TP, Meresse S. 2013. Salmonella T3SSs: Successful mission of the secret(ion) agents. Curr Opin Microbiol 16: $38-44$.

Morizono K, Xie Y, Olafsen T, Lee B, Dasgupta A, Wu AM, Chen IS. 2011. The soluble serum protein Gas6 bridges virion envelope phosphatidylserine to the TAM receptor tyrosine kinase Axl to mediate viral entry. Cell Host Microbe 9: 286-298.

Mostowy S, Cossart P. 2012. Bacterial autophagy: Restriction or promotion of bacterial replication? Trends Cell Biol 22: $283-291$.

Mota LJ, Ramsden AE, Liu M, Castle JD, Holden DW. 2009. SCAMP3 is a component of the Salmonella-induced tubular network and reveals an interaction between bacterial effectors and post-Golgi trafficking. Cell Microbiol 11: 1236-1253.

Murata T, Delprato A, Ingmundson A, Toomre DK, Lambright DG, Roy CR. 2006. The Legionella pneumophila effector protein DrrA is a Rab1 guanine nucleotide-exchange factor. Nat Cell Biol 8: 971-977.

Nanbo A, Imai M, Watanabe S, Noda T, Takahashi K, Neumann G, Halfmann P, Kawaoka Y. 2010. Ebolavirus is internalized into host cells via macropinocytosis in a viral glycoprotein-dependent manner. PLoS Pathog 6: e1001121.

Neu U, Stehle T, Atwood WJ. 2009. The Polyomaviridae: Contributions of virus structure to our understanding of virus receptors and infectious entry. Virology 384: 389-399.

Newton HJ, McDonough JA, Roy CR. 2013. Effector protein translocation by the Coxiella burnetii Dot/Icm type IV secretion system requires endocytic maturation of the pathogen-occupied vacuole. PLOS ONE 8: e54566.

Niebuhr K, Giuriato S, Pedron T, Philpott DJ, Gaits F, Sable J, Sheetz MP, Parsot C, Sansonetti PJ, Payrastre B. 2002. Conversion of PtdIns(4,5) $\mathrm{P}_{2}$ into PtdIns(5)P by the $S$. flexneri effector IpgD reorganizes host cell morphology. EMBO J 21: 5069-5078.
O’Donnell V, LaRocco M, Duque H, Baxt B. 2005. Analysis of foot-and-mouth disease virus internalization events in cultured cells. J Virol 79: 8506-8518.

Omsland A, Cockrell DC, Howe D, Fischer ER, Virtaneva K, Sturdevant DE, Porcella SF, Heinzen RA. 2009. Host cellfree growth of the $\mathrm{Q}$ fever bacterium Coxiella burnetii. Proc Natl Acad Sci 106: 4430-4434.

Ozeri V, Rosenshine I, Ben-Ze'Ev A, Bokoch GM, Jou TS, Hanski E. 2001. De novo formation of focal complex-like structures in host cells by invading Streptococci. Mol Microbiol 41: 561-573.

Patel JC, Galan JE. 2005. Manipulation of the host actin cytoskeleton by Salmonella-All in the name of entry. Curr Opin Microbiol 8: 10-15.

Paumet F, Wesolowski J, Garcia-Diaz A, Delevoye C, Aulner N, Shuman HA, Subtil A, Rothman JE. 2009. Intracellular bacteria encode inhibitory SNARE-like proteins. PloS ONE 4: e7375.

Pelkmans L, Zerial M. 2005. Kinase-regulated quantal assemblies and kiss-and-run recycling of caveolae. Nature 436: $128-133$.

Pelkmans L, Kartenbeck J, Helenius A. 2001. Caveolar endocytosis of simian virus 40 reveals a new two-step vesicular-transport pathway to the ER. Nat Cell Biol 3: 473483.

Pelkmans L, Burli T, Zerial M, Helenius A. 2004. Caveolinstabilized membrane domains as multifunctional transport and sorting devices in endocytic membrane traffic. Cell 118: 767-780.

Pizarro-Cerda J, Cossart P. 2004. Subversion of phosphoinositide metabolism by intracellular bacterial pathogens. Nat Cell Biol 6: 1026-1033.

Pizarro-Cerda J, Cossart P. 2006. Bacterial adhesion and entry into host cells. Cell 124: 715-727.

Pizarro-Cerda J, Bonazzi M, Cossart P. 2010. Clathrin-mediated endocytosis: What works for small, also works for big. BioEssays 32: 496-504.

Pizarro-Cerda J, Kuhbacher A, Cossart P. 2012. Entry of Listeria monocytogenes in mammalian epithelial cells: An updated view. Cold Spring Harb Perspect Med 2: a010009.

Qian M, Cai D, Verhey KJ, Tsai B. 2009. A lipid receptor sorts polyomavirus from the endolysosome to the endoplasmic reticulum to cause infection. PLoS Pathog 5: e1000465.

Quirin K, Eschli B, Scheu I, Poort L, Kartenbeck J, Helenius A. 2008. Lymphocytic choriomeningitis virus uses a novel endocytic pathway for infectious entry via late endosomes. Virology 378: 21-33.

Raff AB, Woodham AW, Raff LM, Skeate JG, Yan L, Da Silva DM, Schelhaas M, Kast WM. 2013. The evolving field of human papillomavirus receptor research: A review of binding and entry. J Virol 87: 6062-6072.

Rejman Lipinski A, Heymann J, Meissner C, Karlas A, Brinkmann V, Meyer TF, Heuer D. 2009. Rab6 and Rab11 regulate Chlamydia trachomatis development and golgin-84-dependent Golgi fragmentation. PLoS Pathog 5: e1000615.

Richterova Z, Liebl D, Horak M, Palkova Z, Stokrova J, Hozak P, Korb J, Forstova J. 2001. Caveolae are involved in the trafficking of mouse polyomavirus virions and 
artificial VP1 pseudocapsids toward cell nuclei. J Virol 75: 10880-10891.

Robibaro B, Hoppe HC, Yang M, Coppens I, Ngo HM, Stedman TT, Paprotka K, Joiner KA. 2001. Endocytosis in different lifestyles of protozoan parasitism: Role in nutrient uptake with special reference to Toxoplasma gondii. Int J Parasitol 31: 1343-1353.

Rojek JM, Perez M, Kunz S. 2008. Cellular entry of lymphocytic choriomeningitis virus. J Virol 82: 1505-1517.

Romano PS, Gutierrez MG, Beron W, Rabinovitch M, Colombo MI. 2007. The autophagic pathway is actively modulated by phase II Coxiella burnetii to efficiently replicate in the host cell. Cell Microbiol 9: 891-909.

Römer W, Pontani L-L, Sorre B, Rentero C, Berland L, Chambon V, Lamaze C, Bassereau P, Sykes C, Gaus K, et al. 2010. Actin dynamics drive membrane reorganization and scission in clathrin-independent endocytosis. Cell 140: $540-553$.

Romero S, Grompone G, Carayol N, Mounier J, Guadagnini S, Prevost MC, Sansonetti PJ, Van Nhieu GT. 2011. ATPmediated Erk1/2 activation stimulates bacterial capture by filopodia, which precedes Shigella invasion of epithelial cells. Cell Host Microbe 9: 508-519.

Rosenshine I, Ruschkowski S, Stein M, Reinscheid DJ, Mills SD, Finlay BB. 1996. A pathogenic bacterium triggers epithelial signals to form a functional bacterial receptor that mediates actin pseudopod formation. $E M B O J$ 15: 2613-2624.

Roy CR, Tilney LG. 2002. The road less traveled: Transport of Legionella to the endoplasmic reticulum. J Cell Biol 158: 415-419.

Russell DG. 2013. The evolutionary pressures that have molded Mycobacterium tuberculosis into an infectious adjuvant. Curr Opin Microbiol 16: 78-84.

Rust MJ, Lakadamyali M, Zhang F, Zhuang X. 2004. Assembly of endocytic machinery around individual influenza viruses during viral entry. Nat Struct Mol Biol 11: $567-$ 573.

Saeed MF, Kolokoltsov AA, Albrecht T, Davey RA. 2010. Cellular entry of Ebola virus involves uptake by a macropinocytosis-like mechanism and subsequent trafficking through early and late endosomes. PLoS Pathog 6: e1001110.

Schelhaas M, Ewers H, Rajamaki ML, Day PM, Schiller JT, Helenius A. 2008. Human papillomavirus type 16 entry: Retrograde cell surface transport along actin-rich protrusions. PLoS Pathog 4: e1000148.

Schelhaas M, Shah B, Holzer M, Blattmann P, Kuhling L, Day PM, Schiller JT, Helenius A. 2012. Entry of human papillomavirus type 16 by actin-dependent, clathrinand lipid raft-independent endocytosis. PLoS Pathog 8: e1002657.

Schmidt FI, Bleck CK, Helenius A, Mercer J. 2011. Vaccinia extracellular virions enter cells by macropinocytosis and acid-activated membrane rupture. EMBO J 30: 36473661.

Seveau S, Bierne H, Giroux S, Prevost MC, Cossart P. 2004 Role of lipid rafts in E-cadherin- and HGF-R/Met-mediated entry of Listeria monocytogenes into host cells. J Cell Biol 166: 743-753.
Seveau S, Tham TN, Payrastre B, Hoppe AD, Swanson JA, Cossart P. 2007. A FRET analysis to unravel the role of cholesterol in Racl and PI 3-kinase activation in the InlB/Met signalling pathway. Cell Microbiol 9: 790-803.

Shen Y, Naujokas M, Park M, Ireton K. 2000. InIB-dependent internalization of Listeria is mediated by the Met receptor tyrosine kinase. Cell 103: 501-510.

Sieczkarski SB, Whittaker GR. 2002. Dissecting virus entry via endocytosis. J Gen Virol 83: 1535-1545.

Simmons G, Gosalia DN, Rennekamp AJ, Reeves JD, Diamond SL, Bates P. 2005. Inhibitors of cathepsin L prevent severe acute respiratory syndrome coronavirus entry. Proc Natl Acad Sci 102: 11876-11881.

Smith J, Manoranjan J, Pan M, Bohsali A, Xu J, Liu J, McDonald KL, Szyk A, LaRonde-LeBlanc N, Gao LY. 2008. Evidence for pore formation in host cell membranes by ESX-1-secreted ESAT-6 and its role in Mycobacterium marinum escape from the vacuole. Infect Immun 76: 5478-5487.

Soldati T, Neyrolles O. 2012. Mycobacteria and the intraphagosomal environment: Take it with a pinch of salt(s)! Traffic 13: 1042-1052.

Sousa S, Cabanes D, Bougneres L, Lecuit M, Sansonetti P, Tran-Van-Nhieu G, Cossart P. 2007. Src, cortactin and Arp2/3 complex are required for E-cadherin-mediated internalization of Listeria into cells. Cell Microbiol 9: 2629-2643.

Stang E, Kartenbeck J, Parton RG. 1997. Major histocompatibility complex class I molecules mediate association of SV40 with caveolae. Mol Biol Cell 8: 47-57.

Starr T, Ng TW, Wehrly TD, Knodler LA, Celli J. 2008. Brucella intracellular replication requires trafficking through the late endosomal/lysosomal compartment. Traffic 9: 678-694.

Stehle T, Gamblin SJ, Yan Y, Harrison SC. 1996. The structure of simian virus 40 refined at $3.1 \AA$ resolution. Structure 4: 165-182.

Stergiou L, Bauer M, Mair W, Bausch-Fluck D, Drayman N, Wollscheid B, Oppenheim A, Pelkmans L. 2013. Integrinmediated signaling induced by simian virus 40 leads to transient uncoupling of cortical actin and the plasma membrane. PloS ONE 8: e55799.

Stoeber M, Stoeck IK, Hanni C, Bleck CK, Balistreri G, Helenius A. 2012. Oligomers of the ATPase EHD2 confine caveolae to the plasma membrane through association with actin. EMBO J 31: 2350-2364.

Sturgill-Koszycki S, Schlesinger PH, Chakraborty P, Haddix PL, Collins HL, Fok AK, Allen RD, Gluck SL, Heuser J, Russell DG. 1994. Lack of acidification in Mycobacterium phagosomes produced by exclusion of the vesicular proton-ATPase. Science 263: 678-681.

Suikkanen S, Saajarvi K, Hirsimaki J, Valilehto O, Reunanen H, Vihinen-Ranta M, Vuento M. 2002. Role of recycling endosomes and lysosomes in dynein-dependent entry of canine parvovirus. J Virol 76: 4401-4411.

Sun E, He J, Zhuang X. 2013. Live cell imaging of viral entry. Curr Opin Virol 3: 34-43.

Swanson JA, Watts C. 1995. Macropinocytosis. Trends Cell Biol 5: 424-428. 
P. Cossart and A. Helenius

Swanson JA, Johnson MT, Beningo K, Post P, Mooseker M, Araki N. 1999. A contractile activity that closes phagosomes in macrophages. J Cell Sci 112: 307-316.

Tagawa A, Mezzacasa A, Hayer A, Longatti A, Pelkmans L, Helenius A. 2005. Assembly and trafficking of caveolar domains in the cell: Caveolae as stable, cargo-triggered, vesicular transporters. J Cell Biol 170: 769-779.

Thanassi DG, Bliska JB, Christie PJ. 2012. Surface organelles assembled by secretion systems of Gram-negative bacteria: Diversity in structure and function. FEMS Microbiol Rev 36: 1046-1082.

Ton-That H, Marraffini LA, Schneewind O. 2004. Protein sorting to the cell wall envelope of Gram-positive bacteria. Biochim Biophys Acta 1694: 269-278.

Townsley AC, Weisberg AS, Wagenaar TR, Moss B. 2006. Vaccinia virus entry into cells via a low-pH-dependent endosomal pathway. J Virol 80: 8899-8908.

Tran Van Nhieu G, Bourdet-Sicard R, Dumenil G, Blocker A, Sansonetti PJ. 2000. Bacterial signals and cell responses during Shigella entry into epithelial cells. Cell Microbiol 2: 187-193.

Tsai B, Gilbert JM, Stehle T, Lencer W, Benjamin TL, Rapoport TA. 2003. Gangliosides are receptors for murine polyoma virus and SV40. EMBO J 22: 4346-4355.

Unsworth KE, Mazurkiewicz P, Senf F, Zettl M, McNiven M, Way M, Holden DW. 2007. Dynamin is required for Factin assembly and pedestal formation by enteropathogenic Escherichia coli (EPEC). Cell Microbiol 9: 438-449.

Valiya Veettil M, Sadagopan S, Kerur N, Chakraborty S, Chandran B. 2010. Interaction of c-Cbl with myosin IIA regulates Bleb associated macropinocytosis of Kaposi's sarcoma-associated herpesvirus. PLoS Pathog 6: e1001238.

van der Schaar HM, Rust MJ, Chen C, van der Ende-Metselaar H, Wilschut J, Zhuang X, Smit JM. 2008. Dissecting the cell entry pathway of dengue virus by single-particle tracking in living cells. PLoS Pathog 4: e1000244.

van der Wel N, Hava D, Houben D, Fluitsma D, van Zon M, Pierson J, Brenner M, Peters PJ. 2007. M. tuberculosis and $M$. leprae translocate from the phagolysosome to the cytosol in myeloid cells. Cell 129: 1287-1298.

Van Nhieu GT, Isberg RR. 1991. The Yersinia pseudotuberculosis invasin protein and human fibronectin bind to mutually exclusive sites on the $\alpha 5 \beta 1$ integrin receptor. $J$ Biol Chem 266: 24367-24375.

Van Nhieu GT, Krukonis ES, Reszka AA, Horwitz AF, Isberg RR. 1996. Mutations in the cytoplasmic domain of the integrin $\beta 1$ chain indicate a role for endocytosis factors in bacterial internalization. J Biol Chem 271: 7665-7672.

Vasta GR. 2009. Roles of galectins in infection. Nat Rev Microbiol 7: 424-438.

Vazquez-Calvo A, Saiz JC, McCullough KC, Sobrino F, Martin-Acebes MA. 2012a. Acid-dependent viral entry. Virus Res 167: 125-137.
Vazquez-Calvo A, Sobrino F, Martin-Acebes MA. 2012b. Plasma membrane phosphatidylinositol 4,5 bisphosphate is required for internalization of foot-and-mouth disease virus and vesicular stomatitis virus. PLoS ONE 7: e45172.

Veiga E, Cossart P. 2005. Listeria hijacks the clathrin-dependent endocytic machinery to invade mammalian cells. Nat Cell Biol 7: 894-900.

Veiga E, Guttman JA, Bonazzi M, Boucrot E, Toledo-Arana A, Lin AE, Enninga J, Pizarro-Cerda J, Finlay BB, Kirchhausen $\mathrm{T}$, et al. 2007. Invasive and adherent bacterial pathogens co-Opt host clathrin for infection. Cell Host Microbe 2: 340-351.

von Bargen K, Gorvel JP, Salcedo SP. 2012. Internal affairs: Investigating the Brucella intracellular lifestyle. FEMS Microbiol Rev 36: 533-562.

Voth DE, Heinzen RA. 2007. Lounging in a lysosome: The intracellular lifestyle of Coxiella burnetii. Cell Microbiol 9: $829-840$.

Waksman G, Hultgren SJ. 2009. Structural biology of the chaperone-usher pathway of pilus biogenesis. Nat Rev Microbiol 7: 765-774.

* Wandinger-Ness A, Zerial M. 2014. Rab proteins and the compartmentalization of the endosomal system. Cold Spring Harb Perspect Biol doi: 10.1101/cshperspect. a022616.

Wang LH, Rothberg KG, Anderson RG. 1993. Mis-assembly of clathrin lattices on endosomes reveals a regulatory switch for coated pit formation. J Cell Biol 123: 11071117.

Wickham TJ, Mathias P, Cheresh DA, Nemerow GR. 1993. Integrins $\alpha v \beta 3$ and $\alpha v \beta 5$ promote adenovirus internalization but not virus attachment. Cell 73: 309-319.

Wilen CB, Tilton JC, Doms RW. 2012. Molecular mechanisms of HIV entry. Adv Exp Med Biol 726: 223-242.

Wong KW, Isberg RR. 2003. Arf6 and phosphoinositol-4phosphate-5-kinase activities permit bypass of the Racl requirement for $\beta 1$ integrin-mediated bacterial uptake. J Exp Med 198: 603-614.

Wong KW, Isberg RR. 2005. Emerging views on integrin signaling via Rac1 during invasin-promoted bacterial uptake. Curr Opin Microbiol 8: 4-9.

Yamauchi Y, Boukari H, Banerjee I, Sbalzarini IF, Horvath P, Helenius A. 2011. Histone deacetylase 8 is required for centrosome cohesion and influenza A virus entry. PLoS Pathog 7: e1002316.

Yu XJ, McGourty K, Liu M, Unsworth KE, Holden DW. 2010. $\mathrm{pH}$ sensing by intracellular Salmonella induces effector translocation. Science 328: 1040-1043.

Zhang Y, Hoppe AD, Swanson JA. 2010. Coordination of Fc receptor signaling regulates cellular commitment to phagocytosis. Proc Natl Acad Sci 107: 19332-19337. 


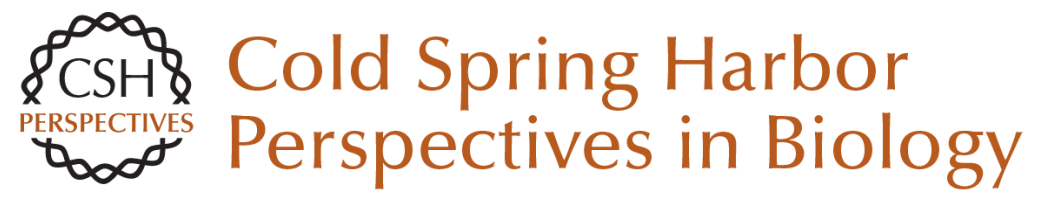

\section{Endocytosis of Viruses and Bacteria}

Pascale Cossart and Ari Helenius

Cold Spring Harb Perspect Biol 2014; doi: 10.1101/cshperspect.a016972

Subject Collection Endocytosis

Endocytosis: Past, Present, and Future Sandra L. Schmid, Alexander Sorkin and Marino Zerial

Rab Proteins and the Compartmentalization of the Endosomal System Angela Wandinger-Ness and Marino Zerial

Cargo Sorting in the Endocytic Pathway: A Key Regulator of Cell Polarity and Tissue Dynamics Suzanne Eaton and Fernando Martin-Belmonte

Unconventional Functions for Clathrin, ESCRTs, and Other Endocytic Regulators in the Cytoskeleton, Cell Cycle, Nucleus, and Beyond: Links to Human Disease

Frances M. Brodsky, R. Thomas Sosa, Joel A. Ybe, et al.

Endocytosis of Viruses and Bacteria Pascale Cossart and Ari Helenius

Lysosomal Adaptation: How the Lysosome

\section{Responds to External Cues} Carmine Settembre and Andrea Ballabio

Reciprocal Regulation of Endocytosis and Metabolism

Costin N. Antonescu, Timothy E. McGraw and Amira Klip

Endocytosis and Autophagy: Exploitation or Cooperation?

Sharon A. Tooze, Adi Abada and Zvulun Elazar
Imaging and Modeling the Dynamics of

Clathrin-Mediated Endocytosis

Marcel Mettlen and Gaudenz Danuser

Endocytic Accessory Factors and Regulation of

Clathrin-Mediated Endocytosis

Christien J. Merrifield and Marko Kaksonen

The Complex Ultrastructure of the Endolysosomal

System Judith Klumperman and Graça Raposo

The Biogenesis of Lysosomes and

Lysosome-Related Organelles J. Paul Luzio, Yvonne Hackmann, Nele M.G. Dieckmann, et al.

Endocytosis, Signaling, and Beyond Pier Paolo Di Fiore and Mark von Zastrow

Clathrin-Independent Pathways of Endocytosis Satyajit Mayor, Robert G. Parton and Julie G. Donaldson

The Role of Endocytosis during Morphogenetic Signaling Marcos Gonzalez-Gaitan and Frank Jülicher

Role of Endosomes and Lysosomes in Human Disease

Frederick R. Maxfield

For additional articles in this collection, see http://cshperspectives.cshlp.org/cgi/collection/

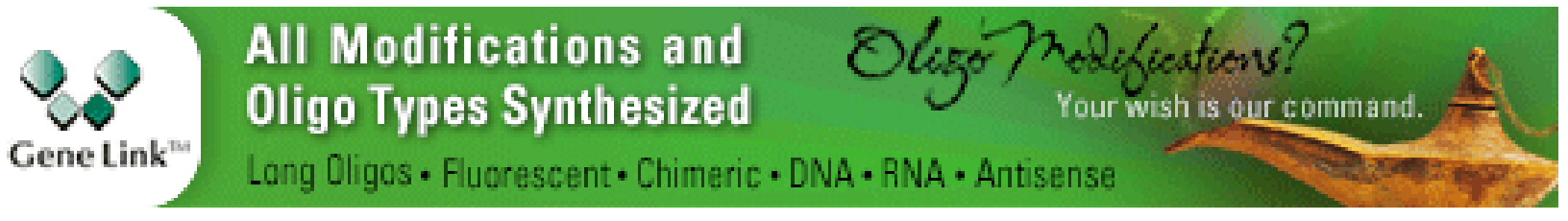


For additional articles in this collection, see http://cshperspectives.cshlp.org/cgi/collection/

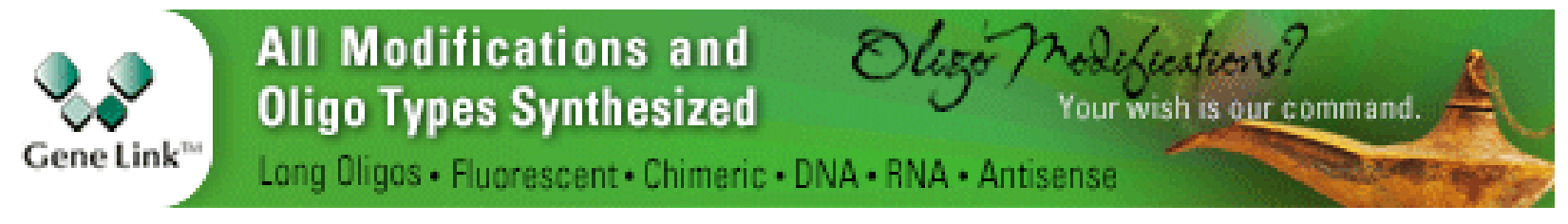

Copyright @ 2014 Cold Spring Harbor Laboratory Press; all rights reserved 